\title{
Predicting seasonal density patterns of California cetaceans based on habitat models
}

\author{
Elizabeth A. Becker ${ }^{1,2, *}$, Karin A. Forney ${ }^{1}$, David G. Foley ${ }^{3,4}$, Raymond C. Smith ${ }^{5}$, \\ Thomas J. Moore ${ }^{6}$, Jay Barlow ${ }^{6}$
}

\author{
${ }^{1}$ Marine Mammal and Turtle Division, Southwest Fisheries Science Center, National Marine Fisheries Service, \\ National Oceanic and Atmospheric Administration, 110 Shaffer Rd, Santa Cruz, California 95060, USA \\ ${ }^{2}$ Ocean Associates Inc., 4007 N. Abingdon Street, Arlington, Virginia 22207, USA \\ ${ }^{3}$ Institute of Marine Sciences, University of California at Santa Cruz, 1000 Shaffer Rd, Santa Cruz, California 95060, USA \\ ${ }^{4}$ Environmental Research Division, Southwest Fisheries Science Center, National Marine Fisheries Service, \\ National Oceanic and Atmospheric Administration, 1352 Lighthouse Ave, Pacific Grove, California 93950, USA \\ ${ }^{5}$ Environmental Research Institute, UCSB, Santa Barbara, California 93106, USA \\ ${ }^{6}$ Marine Mammal and Turtle Division, Southwest Fisheries Science Center, National Marine Fisheries Service, \\ National Oceanic and Atmospheric Administration, 8901 La Jolla Shores Dr., La Jolla, California 92037, USA
}

\begin{abstract}
Temporal variability in species distribution remains a major source of uncertainty in managing protected marine species, particularly in ecosystems with significant seasonal or interannual variation, such as the California Current Ecosystem (CCE). Spatially explicit specieshabitat models have become valuable tools for decision makers assisting in the development and implementation of measures to reduce adverse impacts (e.g. from fishery bycatch, ship strikes, anthropogenic sound), but such models are often not available for all seasons of interest. Broadscale migratory patterns of many of the large whale species are well known, while seasonal distribution shifts of small cetaceans are typically less well understood. Within the CCE, specieshabitat models have been developed based on 6 summer-fall surveys conducted during 1991 to 2008. We evaluated whether the between-year oceanographic variability can inform species predictions during winter-spring periods. Generalized additive models were developed to predict abundance of 4 cetacean species/genera known to have year-round occurrence in the CCE: common dolphins Delphinus spp., Pacific white-sided dolphin Lagenorhynchus obliquidens, northern right whale dolphin Lissodelphis borealis, and Dall's porpoise Phocoenoides dalli. Predictor variables included a combination of temporally dynamic, remotely sensed environmental variables and geographically fixed variables. Across-season predictive ability was evaluated relative to aerial surveys conducted in winter-spring 1991 to 1992, using observed:predicted density ratios, nonparametric Spearman rank correlation tests, and visual inspection of predicted and observed distributions by species. Seasonal geographic patterns of species density were captured effectively for most species, although some model limitations were evident, particularly when the original summer-fall data did not adequately capture winter-spring habitat conditions.
\end{abstract}

KEY WORDS: Cetacean abundance - Habitat-based density model $\cdot$ California Current $\cdot$ Remote sensing · Common dolphin · Pacific white-sided dolphin · Northern right whale dolphin · Dall's porpoise

Resale or republication not permitted without written consent of the publisher

\section{INTRODUCTION}

The abundance and distribution of many pelagic species are highly variable on seasonal, interannual, and decadal time scales (Forney 1999, 2000, Pyper
\& Peterman 1999, Maravelias et al. 2000, Rosenkranz et al. 2001, Koslow et al. 2002), and this temporal variability remains a major source of uncertainty in managing marine resources (Peterman \& Bradford 1987, Forney et al. 1991, 2012, Edwards \& 
Perkins 1992, Taylor \& Gerrodette 1993, Ralls \& Taylor 2000). This is particularly important in dynamic regions like the California Current Ecosystem (CCE), which is defined by high variability at multiple temporal and spatial scales (Hickey 1979). Spatially explicit species-habitat models are increasingly recognized as valuable tools for assessing species distributions and recently have been used to develop conservation strategies for marine mammals (e.g. an Endangered Species Research Theme Section, 'Beyond marine mammal habitat modeling: applications for ecology and conservation,' was dedicated to this topic). The need for effective predictive models of cetacean occurrence and distribution has become more critical for marine resource managers who must select minimal-impact locations or seasons for an increasing number of human activities with the potential to harm cetaceans (e.g. vessel traffic, naval training, fisheries interactions). Quantitative cetacean-habitat models provide a means to assess potential impacts and inform conservation management decisions (Hooker et al. 1999, Cañadas et al. 2002, Torres et al. 2003, Kaschner et al. 2006, Barlow et al. 2009, Gerrodette \& Eguchi 2011, Gilles et al. 2011, Becker et al. 2012a,b, Forney et al. 2012, Goetz et al. 2012, Keller et al. 2012, Redfern et al. 2013).

Habitat-based density models for cetaceans are typically based on sighting and oceanographic data collected during systematic line-transect surveys. Off the US west coast, the abundance of cetaceans was estimated from 6 shipboard line-transect surveys conducted by the Southwest Fisheries Science Center (SWFSC) from July to November 1991 to 2008, covering an area of approximately $1141807 \mathrm{~km}^{2}$ (Barlow 2010). Cetacean sighting data from these surveys have been used to develop and validate habitatbased density models, which provide the best estimates of average cetacean density and distribution off the US west coast for summer and fall (hereafter 'summer' and 'summer models'; Barlow et al. 2009, Becker et al. 2012b, Forney et al. 2012).

Ideally, species-habitat models would be developed using sighting and corresponding environmental data specific to the period of interest. Rough weather conditions in the CCE make it difficult to collect shipboard line-transect data year-round, however, and few studies have assessed cetacean density and distribution in winter and spring (hereafter 'winter'). Most of the systematic survey data that exist for these seasons have been collected during aerial surveys (Dohl et al. 1983, Forney \& Barlow 1998), which do not allow for the collection of complementary in situ oceanographic data, and typically contain too few sightings to build and evaluate predictive habitat models. In the absence of sufficient winter survey data, it is important to evaluate the temporal range of predictions from the summer habitat models, particularly in a temporally dynamic environment. Broadscale seasonal migratory patterns of many of the large whale species have been described (e.g. Calambokidis et al. 2000, 2009, Swartz et al. 2006, Barlow et al. 2011), and although pronounced seasonal distribution shifts of small cetaceans have been identified (Dohl et al. 1986, Green et al. 1992, 1993, Forney \& Barlow 1998), they are typically not as well understood and may vary considerably from year to year.

Although the physical processes responsible for variation in local oceanographic conditions differ on seasonal (Reid et al. 1958, Barber \& Smith 1981, Lynn \& Simpson 1987), interannual (Barber \& Chavez 1983, Schwing et al. 2000), and inter-decadal (McGowan et al. 1998, Mantua \& Hare 2002) time scales, effects on sea surface temperature and other variables are similar (Chavez et al. 2003). If interannual variability in oceanographic conditions during summer is of a similar order of magnitude to seasonal variation, then it might be possible to predict winter population densities for cetacean species that are not highly migratory based on multi-year summer models and remotely sensed oceanographic data for the winter period. Predictive cetacean models primarily have been developed using habitat data that were collected in situ, but Becker et al. (2010) found that satellitederived measures of sea surface temperature (SST) can be effective predictors of cetacean density, thus offering a means of predicting cetacean density and distribution when only remotely sensed environmental data are available.

In this study, we developed generalized additive models (GAMs; Hastie \& Tibshirani 1990) to relate cetacean sighting data from shipboard surveys in the CCE during the summers of 1991 to 2008 to remotely sensed SST and static predictor variables. The resulting models were then used to predict cetacean distribution patterns based on remotely sensed environmental data for winter and spring 1991/92, a period when aerial surveys were conducted within a portion of the study area off California. Models were built for 3 small cetacean species and 1 genus that are known to be present yearround and had sufficient sightings during the winter aerial surveys to evaluate the habitat-based density models. The 3 small cetacean species are: Pacific white-sided dolphin Lagenorhynchus obliquidens, 
northern right whale dolphin Lissodelphis borealis, and Dall's porpoise Phocoenoides dalli. Shortbeaked common dolphins Delphinus delphis and long-beaked common dolphins $D$. capensis have similar pigmentation and morphology (Rosel et al. 1994), and were recorded only as Delphinus sp. during the aerial surveys (Forney et al. 1995, Forney \& Barlow 1998), so the present analysis was conducted for the genus.

The aerial survey data were used to evaluate whether models constructed for summer using the extensive shipboard sighting data could predict broad distribution and density patterns during the winter period. This approach provided the advantages of a robust dataset for model construction (the shipboard data) and a test dataset during a different season for evaluation (the aerial survey data). The purpose of this study was to assess whether species-environment models developed using shipboard survey data collected during summer improve our ability to predict cetacean density for winter as compared to a 'null' model (i.e. density estimates derived from summer shipboard surveys without consideration of environmental data). Results are examined in light of known cetacean distribution patterns documented from previous California cetaceanhabitat studies.

\section{METHODS}

\section{Field methods}

\section{SWFSC US west coast shipboard surveys}

Cetacean sighting data used to construct the predictive models were collected off the US west coast by SWFSC during the summer and fall (July through early December) of 1991, 1993, 1996, 2001, 2005, and 2008 using systematic line-transect methods (Buckland et al. 2001). Barlow \& Forney (2007) provided detailed descriptions of the survey methods. The amount of survey effort varied among years, but transect coverage was roughly uniform throughout the study area (Fig. 1), and cetacean data collection procedures were consistent across all surveys (Kinzey et al. 2000, Barlow 2010). During daylight hours, 2 observers used pedestal-mounted $25 \times 150$ binoculars to search for marine mammals from the flying bridge of the ship. A third observer searched by eye or with $7 \times$ handheld binoculars and recorded both sightings and survey conditions. When cetaceans were detected, the ship typically diverted from the transect line to estimate group size and identify the species present. All cetaceans sighted were identified to the lowest taxonomic level possible. To build the shipboard models, we used approximately $66709 \mathrm{~km}$ of on-effort survey data (Fig. 1) collected in Beaufort sea states of 5 or lower.

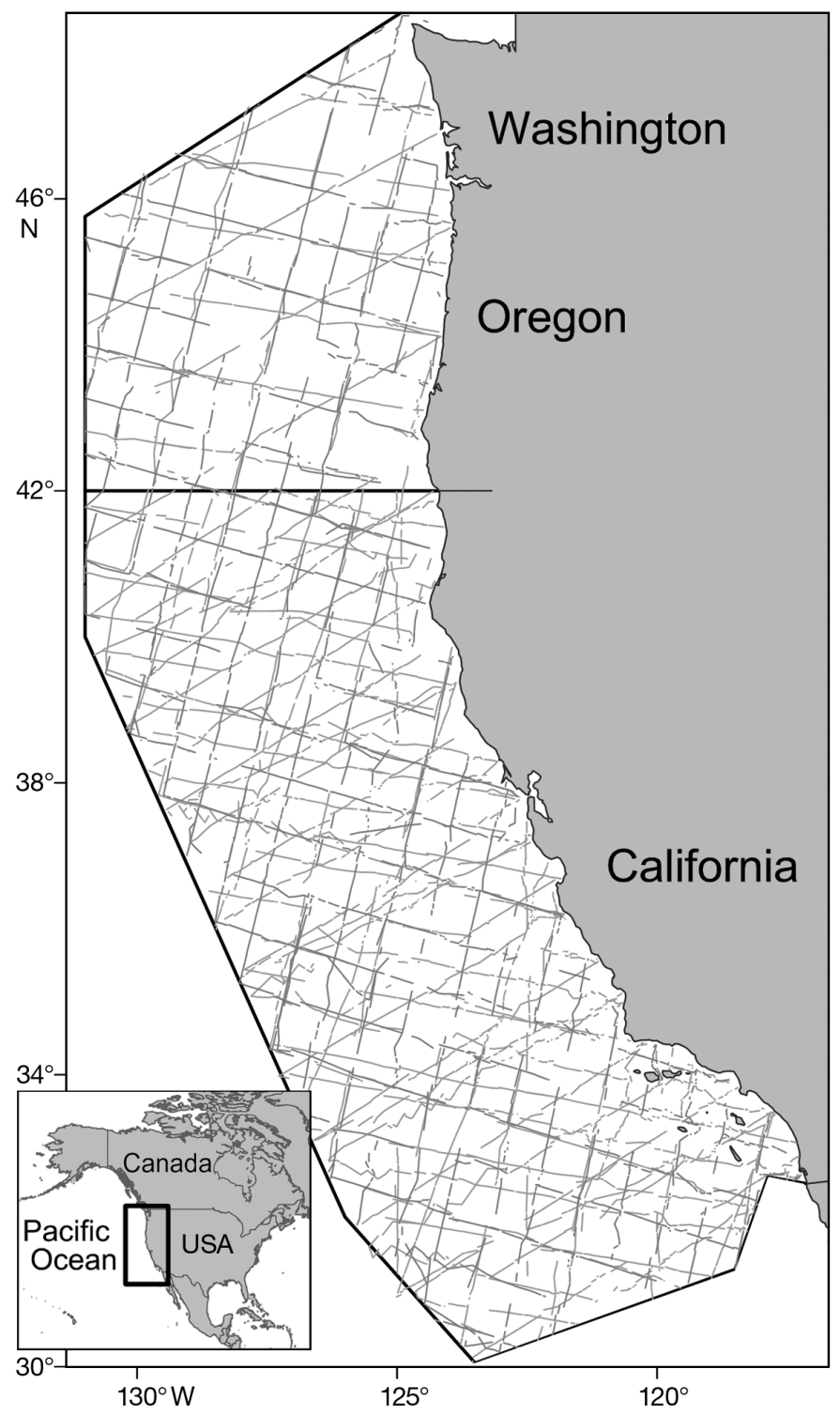

Fig. 1. Completed transects for the systematic shipboard surveys conducted during late July through early December 1991, 1993, 1996, 2001, 2005, and 2008 off the US west coast in Beaufort sea states of 0 to 5 . The black line represents the boundary of the US west coast study area, with the horizontal division indicating the northern extent of the California study area. One degree of latitude $=111 \mathrm{~km}$ 


\section{SWFSC California aerial surveys}

Cetacean sighting data were collected during aerial surveys conducted by SWFSC off California in March to April 1991 and February to April 1992. Detailed descriptions of aerial survey field methods have been published previously (Carretta \& Forney 1993, Forney et al. 1995, Forney \& Barlow 1998), and pertinent aspects are summarized here. The transects followed 2 overlapping grids designed to survey systematically along the entire California coast out to $185 \mathrm{~km}$ off central and northern California and 278 km off southern California (Fig. 2), encompassing approximately $264000 \mathrm{~km}^{2}$ of the nearshore portion of the shipboard study area off California. Aircraft were outfitted with 2 bubble windows for unobstructed lateral viewing and a belly port for downward viewing. The survey team consisted of 3 observers: 2 primary observers who searched through the left and right bubble windows and a secondary observer who used the belly window to search the trackline and report sightings missed by the primary team. In addition, a data recorder positioned next to the pilot recorded

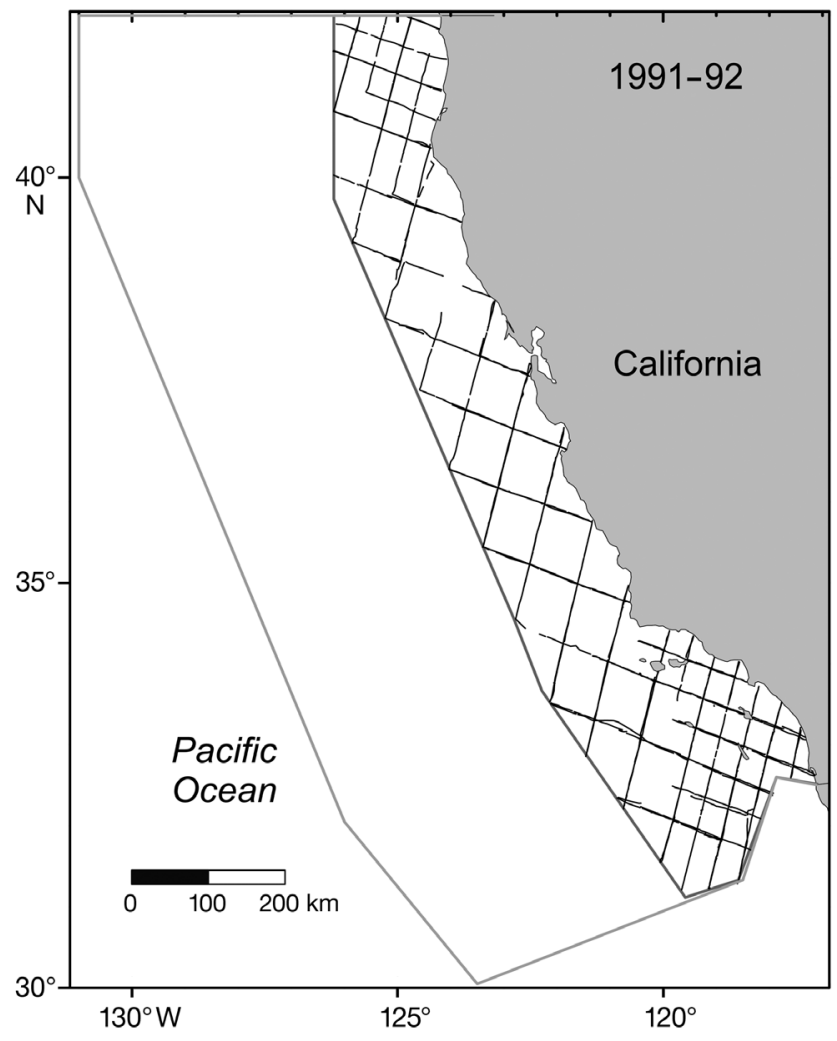

Fig. 2. Completed transects for the systematic aerial surveys conducted off California in March to April 1991 and February to April 1992. The light gray line west and offshore of the aerial study area marks the extent of the shipboard study area off California sighting information and environmental conditions using a laptop computer connected to the aircraft's navigation system. When cetaceans were sighted, the aircraft circled over the animals to allow observers to identify species and estimate group size. Any additional sightings made after the aircraft had diverted from the trackline were not included in the present analysis.

\section{Analytical methods}

We examined the across-season predictive ability of the GAMs using a 2-step process in which (1) species-habitat models were constructed using the summer shipboard sighting data and associated environmental variables, and (2) the resulting models were used to predict cetacean encounter rates, group sizes, and densities based on environmental conditions during the winter aerial survey period. To create samples for modeling, cetacean survey data from the 6 shipboard surveys were separated into continuous transect segments of approximately $5 \mathrm{~km}$ length as described by Becker et al. (2010). The $5 \mathrm{~km}$ length was selected because the study area is characterized by strong cross-shore gradients (Palacios et al. 2006), and we wanted to be able to capture this variability in the static predictors. Following the guidelines of Buckland et al. (2001), sighting data were truncated at $3.3 \mathrm{~km}$ for the delphinids and $2.2 \mathrm{~km}$ for Dall's porpoise (Barlow 2003) to eliminate the most distant groups observed.

Species-specific sighting information (number of encounters, mean group size) and environmental data were assigned to each segment based on the segment's geographical midpoint. Environmental data included as potential predictor variables in the models were: satellite-derived estimates of SST, water depth, bathymetric slope, aspect (i.e. slope direction), and distance to the $200 \mathrm{~m}$ isobath. The $200 \mathrm{~m}$ isobath represents the shelf break for many areas of the California coast, and is a potentially important habitat feature for the species considered in the present analysis (Barlow et al. 2009, Becker et al. 2010, Forney et al. 2012). Bathymetric variables were derived from ETOPO1 (Amante \& Eakins 2009), a 1 arc-minute global-relief model; we used negative values of the distance to the $200 \mathrm{~m}$ isobath in waters shallower than $200 \mathrm{~m}$ to differentiate shelf from slope waters. Slope and aspect were calculated using ArcGIS Spatial Analyst (Version 10.1, ESRI).

Satellite-based SST data derived using optimal interpolation methods (Reynolds \& Smith 1994) were 
used in the models as they provide a daily, gap-free SST product at $25 \mathrm{~km}$ spatial resolution (Reynolds et al. 2007). These 'blended' SST data combine in situ and infrared sensor measurements to virtually eliminate data gaps due to cloud cover, and have been used successfully in habitat-based density models for cetaceans (Becker et al. 2012a).

Average sea state (measured on the Beaufort scale) for each segment was included as a continuous predictor variable in our models to account for the variability in sighting conditions (Barlow et al. 2001), but segments with average sea state values exceeding Beaufort 5 were excluded from the analysis because small cetaceans cannot reliably be detected in sea states above Beaufort 5 (Barlow \& Forney 2007). Although conventional line-transect analyses have generally restricted the analyses for Dall's porpoise, the most cryptic species in this study, to include only calm conditions (Beaufort sea states 0-2; Barlow 2003, 2010, Barlow \& Forney 2007), we included sea states up to Beaufort 5 when developing the habitat-based models because the limited segments with calm conditions did not cover the full range of habitats for Dall's porpoise in the study area. For all species, sea state was included as a predictor variable within the models to account for detection differences.

\section{Model structure and development}

Detailed descriptions of the model-building process can be found in Barlow et al. (2009), Becker et al. (2010), and Forney et al. (2012); pertinent information is briefly summarized here. For each species/genus, we used GAMs to relate encounter rate (number of sightings) and group size to the habitat variables described above. The encounter rate and group size GAMs were built using the step.gam function in $\mathrm{S}+$ (Version 8.2 for Windows, Tibco Software). We developed Poisson GAMs, in which overdispersion was corrected using a quasi-likelihood model, to fit the number of sightings for a given segment. Although the target segment length for modeling was $5 \mathrm{~km}$, actual segment length varied slightly (see Becker et al. 2010); therefore, segment length was included as an offset term in the models to standardize each sample for effort. Group size models were built using the natural log of group size as the response variable and an identity link function, following the methods of Ferguson et al. (2006). Group size models were built using only those segments that contained sightings.
We used a stepwise forward/backward variable selection procedure in which each model was fit 3 times to ensure that all terms were tested and to improve the dispersion parameter estimate used to assess the final model (Ferguson et al. 2006). Akaike's information criterion (Akaike 1973) was used in step.gam as the basis for selecting the variables and degrees of freedom for the cubic smoothing splines in each model. A maximum of 3 degrees of freedom in our smoothing splines was specified to capture non-linear relationships without adding unrealistic complexity to the functions (Forney 2000, Ferguson et al. 2006). We used the percentage of explained deviance to assess model fit and ratios of observed to predicted animals to assess the accuracy of the within-season (summer) predictions. Previous studies using these survey data and similar methods have validated the summer models using cross validation (Barlow et al. 2009, Becker et al. 2010, Forney et al. 2012), predictions on novel data sets (Barlow et al. 2009, Becker et al. 2012a, Forney et al. 2012), and expert opinion (Barlow et al. 2009, Becker et al. 2012b, Forney et al. 2012).

Density $\left(D\right.$, ind. $\mathrm{km}^{-2}$ ) for each species was estimated by incorporating the final encounter rate and group size model results into the standard line-transect equation (Buckland et al. 2001):

$$
D=\left(\frac{\mathrm{n}}{L}\right) \times s \times \frac{1}{2 \times \mathrm{ESW} \times g(0)}
$$

where $\mathrm{n} / L$ is the predicted encounter rate (number of sightings per unit length of trackline in $\mathrm{km}), s$ is the predicted group size, ESW is the effective strip halfwidth in $\mathrm{km}$, or $1 / f(0)$ where $f(0)$ is the probability density function evaluated at 0 perpendicular distance (i.e. on the trackline), and $g(0)$ is the probability of detecting a group of animals on the trackline. We relied on published values of $f(0)$ (or ESW) and $g(0)$ for each species as estimated from a portion of the same summer survey data (Barlow 2003) and the specific winter survey data (Forney \& Barlow 1998). For the delphinids, published $f(0)$ and $g(0)$ values were stratified by group size and, therefore, we weighted $f(0)$ and $g(0)$ values based on the number of small and large groups observed during the surveys for our density calculations. To account for potential seasonal differences in group size in our density estimates, the weighted correction factors were derived separately for each season for the entire study area, based on observed group sizes for all years pooled for the respective season. For Dall's porpoise, published $f(0)$ and $g(0)$ values were available only for Beaufort conditions of 0 to 2 . The appli- 
cation of these $f(0)$ and $g(0)$ values in our study, which included sea states of 0 to 5 , resulted in a downward bias in our density estimates for this species, but allows relative comparisons among seasons.

The segment-specific density predictions from the models were interpolated to the entire study area using inverse distance weighting as described by Becker et al. (2010). This weighting method gives points closer to each grid node greater influence than those farther away, and has been used in similar habitat-based density modeling studies (Ferguson et al. 2006, Barlow et al. 2009, Becker et al. 2012a,b, Forney et al. 2012). Grids were created for each of the 6 ship survey years, and the individual grid cells were averaged across all years to calculate mean species density and its interannual variance. Interannual variability in population density due to movement of animals within or outside of the study areas has been determined to be the greatest source of uncertainty in these models (Barlow et al. 2009, Forney et al. 2012), and we focused on this source of uncertainty to produce approximate estimates of variance and log-normal 90\% confidence intervals for the summer spatial density estimates.

\section{Evaluation of model predictive ability}

Three different approaches were used to evaluate the between-season predictive ability of our summer models: (1) a nonparametric Spearman rank correlation test, (2) visual inspection of the observed winter sighting locations relative to the model-predicted density patterns, and (3) a comparison of the modeled density estimates to those derived from standard line-transect analyses ('observed densities') within the study area. For the correlation test, predictive ability was based on a comparison of the models' ranked predicted values across 6 geographic strata to those derived from the actual survey data for each species' encounter rate, group size, and density. To enable a rank analysis, we stratified the study area into 6 regions (Fig. 3). Point Arguello was selected as the dividing line between the northern and southern strata because the Point Arguello/Point Conception region is a known biogeographic boundary, marking the range limits of many marine species (Valentine 1973, Briggs 1974, Newman 1979, Doyle 1985). The northern and southern regions were further stratified roughly by water depth: shelf = waters from the coast to $200 \mathrm{~m}$ deep; slope = waters between 200 and $2000 \mathrm{~m}$ deep; and abyssal plain = waters deeper than $2000 \mathrm{~m}$. Visual inspection of survey effort plots con-

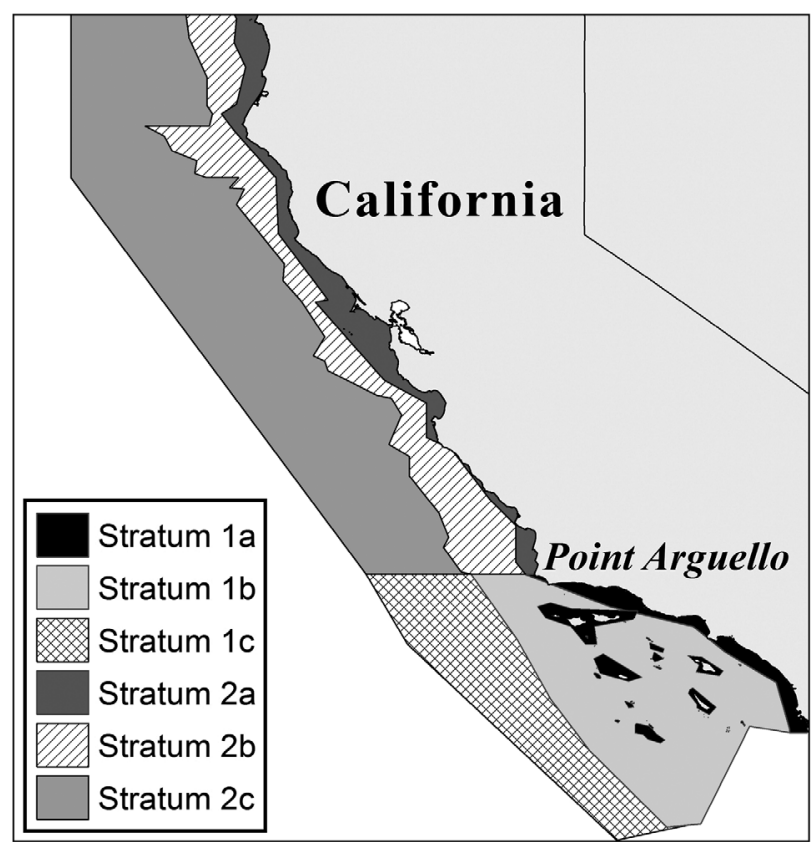

Fig. 3. Geographic strata used for the Spearman rank correlation tests

firmed that effort was relatively uniform within each stratum (i.e. to reduce potential bias resulting from concentrated effort in a portion of a stratum). Results from the Spearman rank correlation tests were compared to results obtained from a 'null' model, defined as the density derived from summer shipboard surveys without consideration of environmental data.

In addition to the rank correlation tests, the betweenseason predictive power of the summer models was evaluated using ratios of observed to predicted species abundance and comparisons of the predicted values to $95 \%$ confidence intervals of the observed values. The mean observed abundances were derived using line-transect analyses (Forney et al. 1995, Forney \& Barlow 1998), and although these estimates are not necessarily unbiased, they are currently the standard measure used to estimate cetacean abundance. Bootstrap 95\% confidence intervals were recalculated from the original line-transect analysis (Forney et al. 1995) using the $\mathrm{BC}_{\mathrm{a}}$ method described by Efron \& Tibshirani (1993) that allows for bias correction and acceleration.

Some differences in platform-specific biases deserve consideration when comparing densities estimated from aerial and shipboard survey data. The magnitude of availability bias (Marsh \& Sinclair 1989) for all species is more important during aerial than shipboard surveys, given the shorter time that any given part of the ocean is in view (Forney \& 
Barlow 1998). During a shipboard survey, availability bias is minimal for the species considered in this analysis and almost negligible for Delphinus spp. that typically occur in large groups. Conversely, during aerial surveys, availability bias is likely for all species considered here, although it is considered to be relatively small for Delphinus spp. (Forney \& Barlow 1998). Correction factors for perception bias (Marsh \& Sinclair 1989) from the aerial surveys are available for the 4 taxa considered here; however, estimates of availability bias were made only for Dall's porpoise (Forney \& Barlow 1998). The aerial survey abundance estimates for winter are thus expected to be biased low for Pacific whitesided dolphin and northern right whale dolphin.

To further evaluate the models' predictive ability, density estimates for each segment were smoothed on a grid resolution of approximately $25 \mathrm{~km}$, and the resultant predictions of distribution and density were visually compared with actual sightings made during the winter aerial surveys. Smoothing was done using inverse distance weighting interpolation as described in the previous subsection for the modeled summer density estimates. The human eye is often superior to statistics for comparing patterns (Wang et al. 2004), particularly in data-limited cases where more advanced spatial methods cannot be used, and this approach provided a means to visually evaluate the models' between-season predictive power.

\section{RESULTS}

Barlow (2010) provided information on the search effort, number of species sighted, and associated line-transect abundance estimates for the 1991 to 2008 shipboard surveys. Similar information on the 1991 to 1992 aerial surveys was provided by Forney et al. (1995) and Forney \& Barlow (1998). Our analysis included 1 warm-temperate/tropical genus (common dolphin) and 3 cold-temperate species (Pacific white-sided dolphin, northern right whale dolphin, Dall's porpoise), all known to be present year-round off California but exhibiting significant seasonal differences in abundance and/or distribution (Forney \& Barlow 1998).

\section{Summer models}

For all taxa, the habitat relationships included in the final encounter rate GAMs built with the summer shipboard data were similar to those observed in previous studies (Table 1, Fig. 4; Barlow et al. 2009, Becker et al. 2010, 2012b, Forney et al. 2012). Encounters with common dolphin were highest in the warmest waters in the study area, with encounters dropping substantially in water temperatures below about $16^{\circ} \mathrm{C}$ (Fig. 4a). A bimodal depth distribution was evident in the encounter rate GAM for common dolphin, with fewest encounters in waters approximately 2000 to $3000 \mathrm{~m}$ deep. The encounter rate models for Pacific white-sided dolphin and northern right whale dolphin were similar, both showing highest encounters in cooler waters over the continental shelf and slope, with a substantial drop in encounters in water temperatures greater than about $16^{\circ} \mathrm{C}$ (Fig. $4 \mathrm{~b}, \mathrm{c}$ ). Highest encounters of Dall's porpoise occurred in cool northern shelf and slope waters, with encounters dropping substantially in water temperatures greater than approximately $17^{\circ} \mathrm{C}$ (Fig. 4d).

The percentage of deviance explained by both the encounter rate and group size models was similar to previous studies (Barlow et al. 2009, Becker et al. 2010, 2012b, Forney et al. 2012). The percentage of deviance explained by the encounter rate models ranged from $15 \%$ (northern right whale dolphin) to $34 \%$ (Dall's porpoise) and from 2\% (common dolphins) to $30 \%$ (northern right whale dolphin) for the group size models (Table 2). Ratios of observed to predicted abundance summarized over all years for the entire study area indicate that the summer models accurately predicted the abundance of these 4 species during the summer season, as all ratios were within $3 \%$ of unity (Table 2 ).

\section{Across-season predictive ability of summer models}

Rank correlation tests

Despite the relatively high percentage of explained deviance for the Pacific white-sided dolphin and northern right whale dolphin group size models (29 and $30 \%$, respectively), they were not effective at predicting spatial variability in group size during the winter, as indicated by the rank correlation test (Table 3). Conversely, the encounter rate model predictions for all species except northern right whale dolphin were better than the null model, and this difference was significant $(p<0.05)$ for both common dolphins and Dall's porpoise.

The summer models' ability to predict winter densities across geographic strata exceeded that of the 


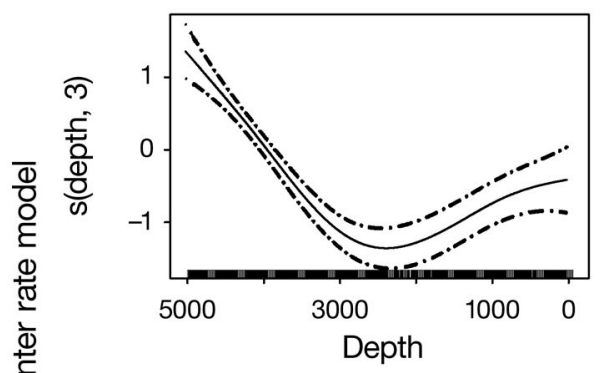

(a) Common dolphins
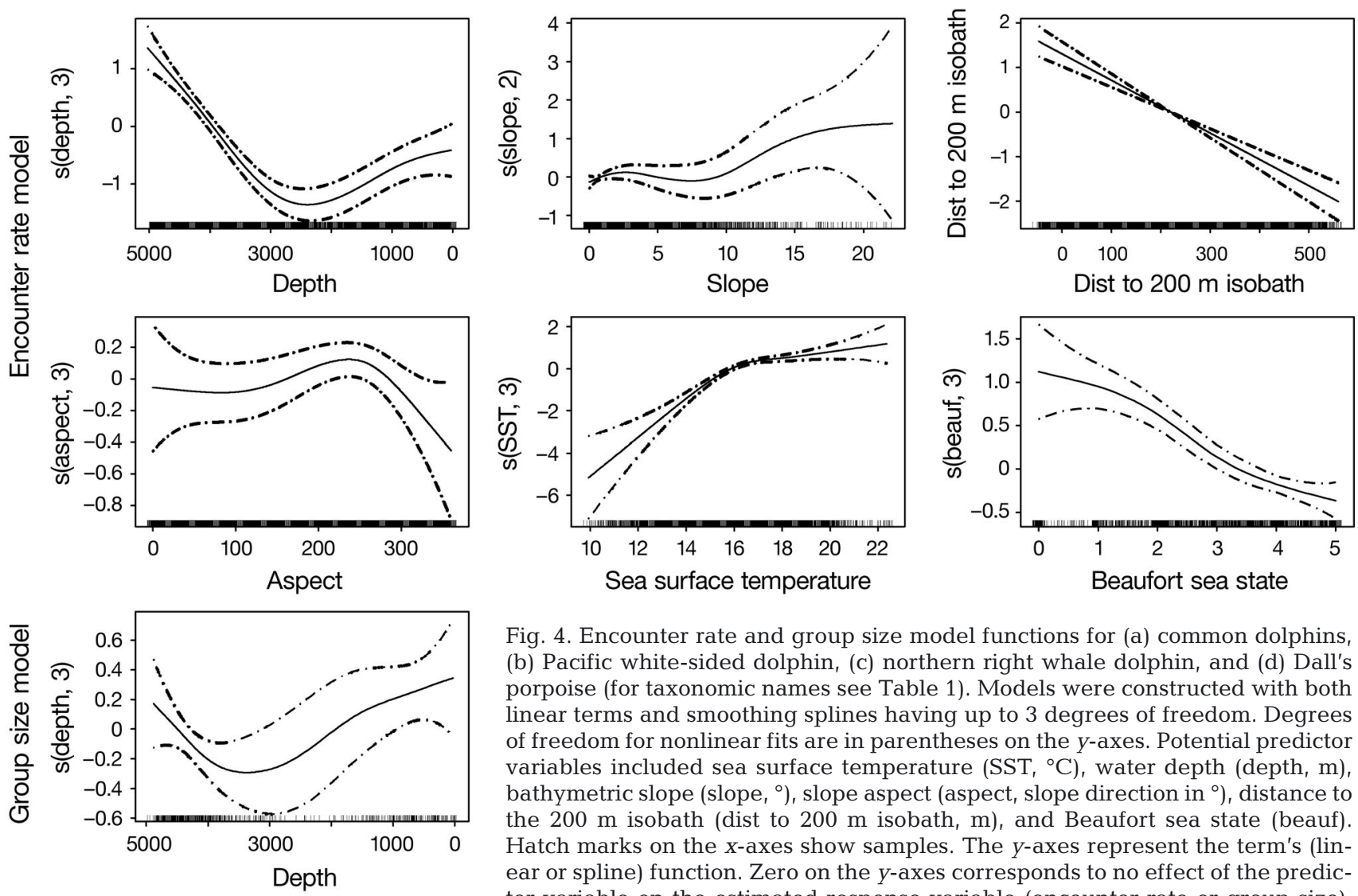

Fig. 4. Encounter rate and group size model functions for (a) common dolphins, (b) Pacific white-sided dolphin, (c) northern right whale dolphin, and (d) Dall's porpoise (for taxonomic names see Table 1). Models were constructed with both linear terms and smoothing splines having up to 3 degrees of freedom. Degrees of freedom for nonlinear fits are in parentheses on the $y$-axes. Potential predictor variables included sea surface temperature $\left(\mathrm{SST}^{\circ}{ }^{\circ} \mathrm{C}\right)$, water depth (depth, $\left.\mathrm{m}\right)$, bathymetric slope (slope, ${ }^{\circ}$ ), slope aspect (aspect, slope direction in ${ }^{\circ}$ ), distance to the $200 \mathrm{~m}$ isobath (dist to $200 \mathrm{~m}$ isobath, $\mathrm{m}$ ), and Beaufort sea state (beauf). Hatch marks on the $x$-axes show samples. The $y$-axes represent the term's (linear or spline) function. Zero on the $y$-axes corresponds to no effect of the predictor variable on the estimated response variable (encounter rate or group size). Scaling of $y$-axis varies among predictor variables to emphasize model fit. The dashed lines reflect $2 \times$ standard error bands (i.e. $95 \%$ confidence interval) null model for 3 of the 4 taxa (common dolphins, northern right whale dolphin, and Dall's porpoise). For both the common dolphin and Dall's porpoise models, their ability to effectively predict spatial density patterns in winter was significantly better than the null model ( $\mathrm{p}<0.05$; Table 3$)$.
Visual inspection of density plots

Visual comparisons of predicted winter densities versus observed sightings from the aerial surveys suggest that the predictions were better than indicated by the coarse-scale rank correlation tests, as

Table 1. Predictor variables included in the final encounter rate (ER) and group size (GS) models for the 1991 to 2008 summer/fall survey data. The expression $\mathrm{s}(x, n)$ indicates a non-parametric smoothing spline of the variable $x$ with $n$ degrees of freedom. GAM: generalized additive model, SST: sea surface temperature, depth: water depth, slope: bathymetric slope, aspect: slope aspect, dist200: distance to the $200 \mathrm{~m}$ isobath, beauf: Beaufort sea state, offset: offset[ln(effective distance searched in km)]

\begin{tabular}{|lll|}
\hline Species & Model & GAM \\
\hline Common dolphins & ER & $\mathrm{s}($ depth, 3) + s(slope, 2) + dist200 + s(aspect, 3) + s(SST, 3) + s(beauf, 3) + offset \\
Delphinus spp. & GS & $\mathrm{s}($ depth, 3) \\
Pacific white-sided dolphin & ER & $\mathrm{s}($ depth, 3) + dist200 + s(SST, 3) + s(beauf, 3) + offset \\
Lagenorhynchus obliquidens & GS & $\mathrm{s}($ depth, 3) + dist200 + s(beauf, 3) \\
Northern right whale dolphin & ER & $\mathrm{s}($ depth, 3) + s(SST, 3) + s(beauf, 3) + offset \\
Lissodelphis borealis & GS & $\mathrm{s}($ depth, 2) + dist200 + aspect + SST + s(beauf, 2) \\
Dall's porpoise Phocoenoides dalli & ER & $\mathrm{s}($ depth, 3) + s(slope, 2) + s(dist200, 3) + s(SST, 3) + s(beauf, 3) + offset \\
& GS & $\mathrm{s}($ slope, 3) + dist200 + s(SST, 3) + beauf \\
\hline
\end{tabular}




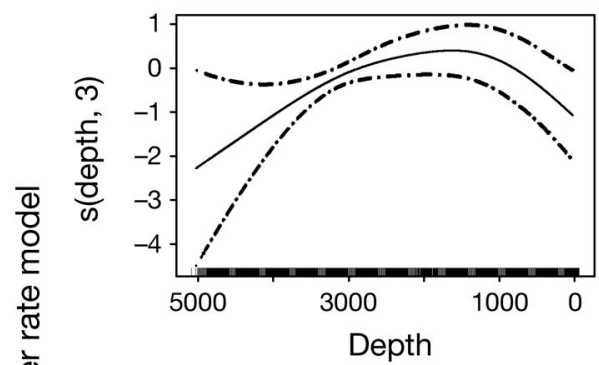

(b) Pacific white-sided dolphin
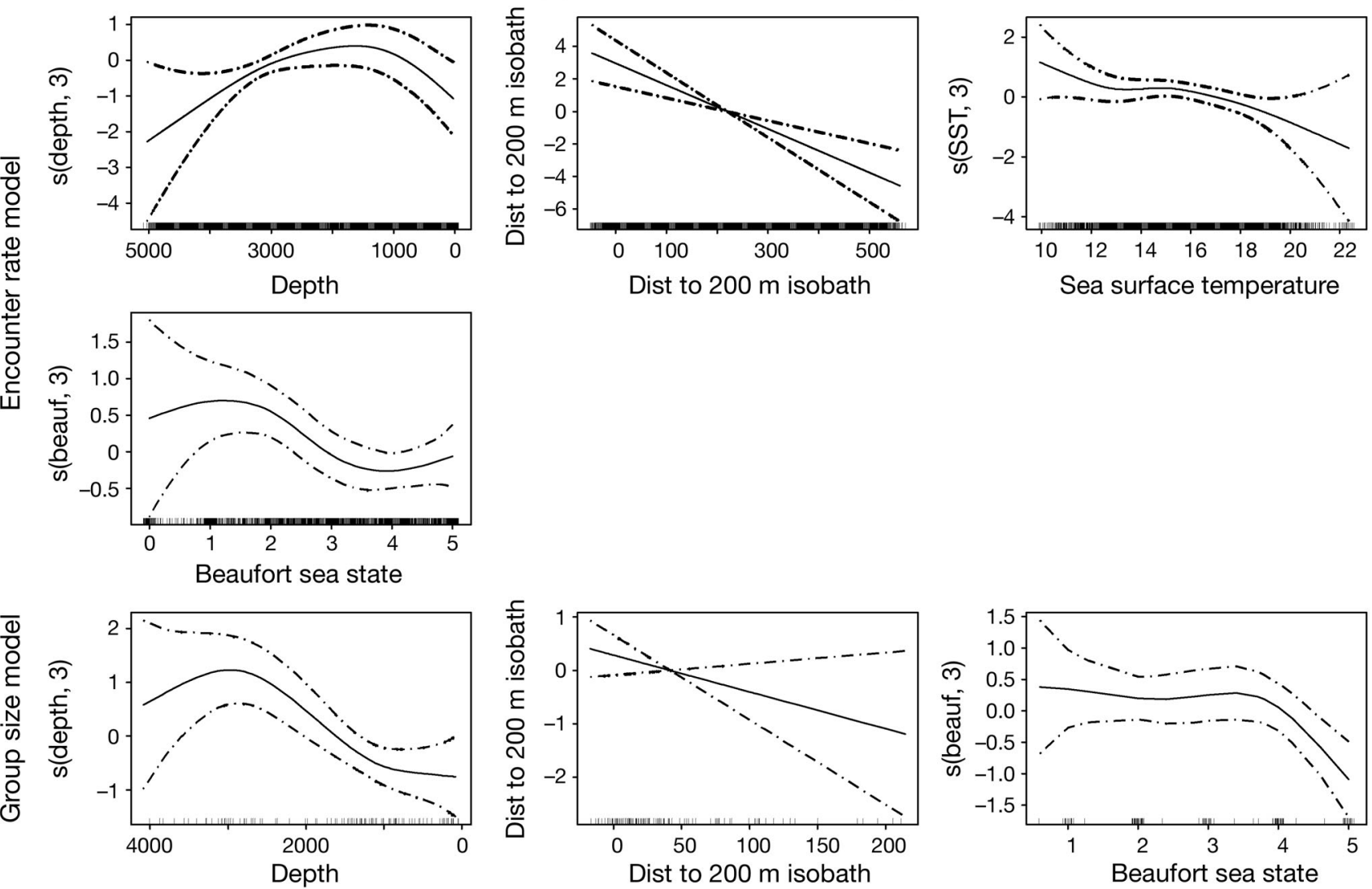

Fig. 4 (continued)

shifts in distribution were captured for all 4 taxa (Fig. 5). Further, for all but northern right whale dolphin, the winter predictions fell largely within the $90 \%$ confidence interval (as derived from interannual variability in summer density patterns) of the predictions based on the summer data, suggesting that interannual variability is comparable to seasonal variability for the remaining 3 taxa (Fig. 6).

Table 2. Percentage of deviance explained by the 1991-2008 encounter rate and group size models for each species, and the ratio of the observed to model-predicted study area density estimates for the summer/fall shipboard surveys (Obs/pred). Taxonomic names are given in Table 1

\begin{tabular}{|c|c|c|c|}
\hline \multirow[t]{2}{*}{ Species } & \multicolumn{2}{|c|}{ Explained deviance } & \multirow{2}{*}{$\begin{array}{l}\text { Obs/ } \\
\text { pred }\end{array}$} \\
\hline & $\begin{array}{l}\text { Encounter } \\
\text { rate model }\end{array}$ & $\begin{array}{c}\text { Group } \\
\text { size model }\end{array}$ & \\
\hline Common dolphins & 15.5 & 2.1 & 0.97 \\
\hline Pacific white-sided dolphin & 23.5 & 29.1 & 0.98 \\
\hline Northern right whale dolphin & 14.8 & 29.7 & 1.01 \\
\hline Dall's porpoise & 33.7 & 10.8 & 1.00 \\
\hline
\end{tabular}

Observed:predicted abundance estimates

Winter abundance estimates predicted by the summer habitat models fell within the $95 \%$ confidence intervals of the standard line-transect analysis of the winter aerial survey data for all species except northern right whale dolphin, for which the modeled abundance estimate was more than 3 times higher than the line-transect point estimate (Table 4). The modeled abundance estimate for Dall's porpoise was very similar to that derived using standard linetransect analyses, while the modeled abundance estimates for Pacific white-sided dolphin and common dolphins were lower than the line-transect derived estimates, and for the latter genus substantially so (almost half; Table 4).

\section{DISCUSSION}

In this study we evaluated whether summer/fall habitat-based density models developed based on multiple years of survey data can capture enough of 


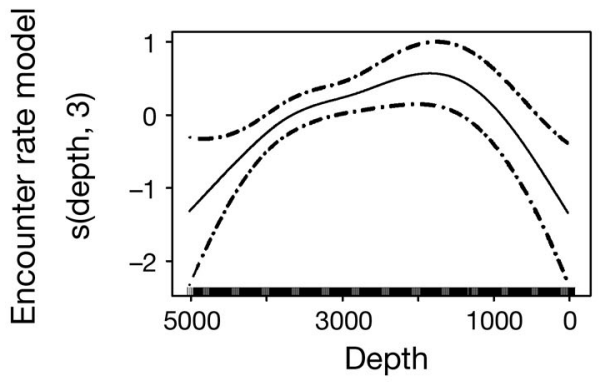

(c) Northern right whale dolphin
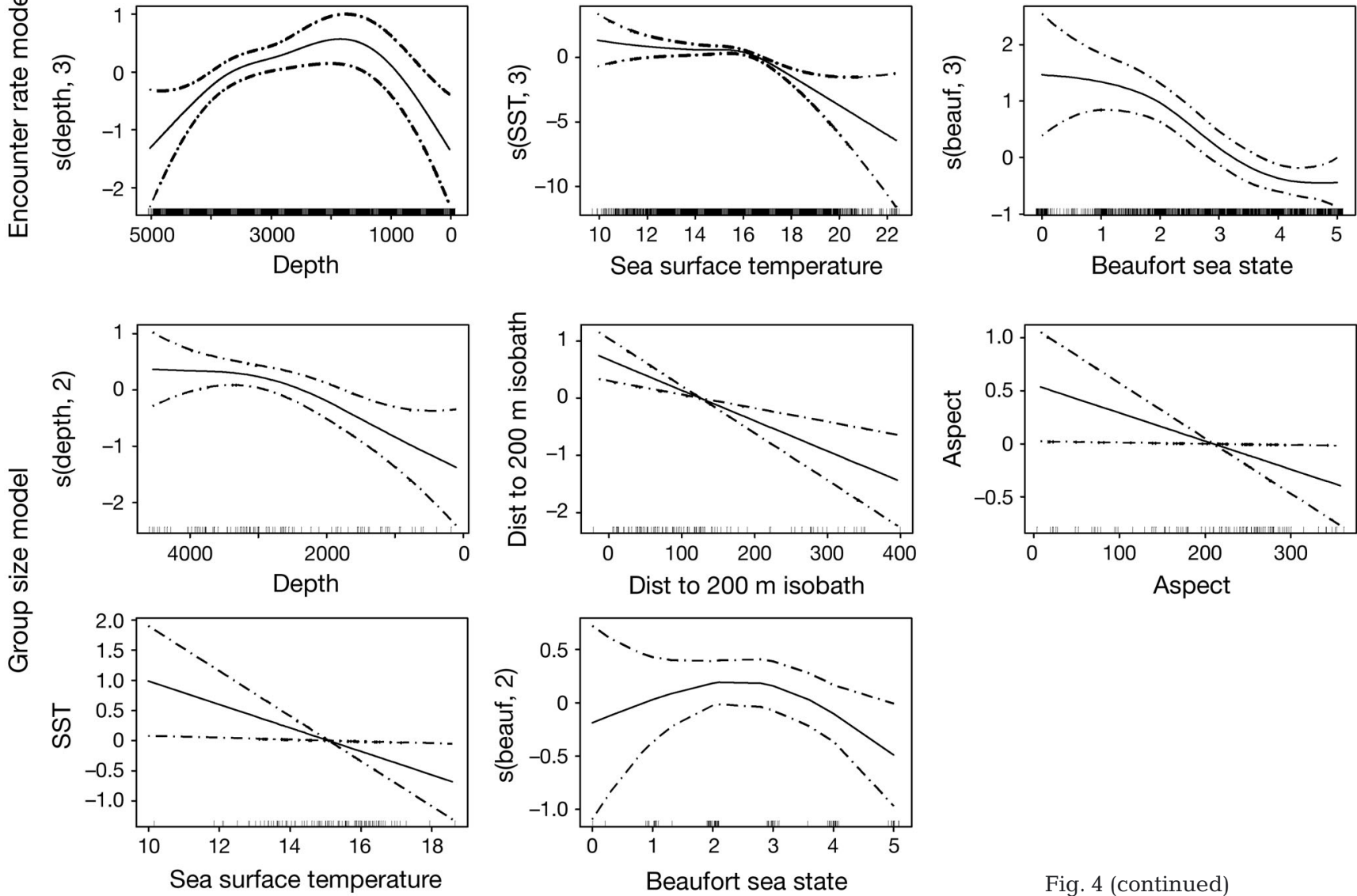

Fig. 4 (continued)

the temporal oceanographic variability to predict species density patterns during winter/spring periods. Based on the nonparametric rank correlation test, individual models for common dolphin, northern right whale dolphin, and Dall's porpoise provided increased ability to predict distribution patterns across seasons, while estimates based on a null model (observations

Table 3. Summary of Spearman rank correlation coefficients (r). 'Null' values are those estimated from the summer/fall shipboard surveys using standard line-transect methods in the absence of environmental data. 'Model' values are the generalized additive models built with the summer/fall shipboard data predicting on environmental conditions during the winter/spring survey periods. The critical value at $\alpha=0.05$ (1-tailed test) with 5 degrees of freedom is rcrit $=0.829$ (i.e. values are significant if larger). Significant correlations are marked with an asterisk $\left({ }^{*}\right)$, and cases for which the model-predicted values did better than the null model are shown in bold. Taxonomic names are given in Table 1

\begin{tabular}{|lrrrrrr|}
\hline \multirow{2}{*}{ Species } & \multicolumn{2}{c}{ Encounter rate } & \multicolumn{2}{c|}{ Group size } & \multicolumn{2}{c|}{ Density } \\
& Null & Model & Null & Model & Null & Model \\
& & & & & & \\
Common dolphins & 0.757 & $\mathbf{0 . 9 8 6}^{*}$ & -0.300 & $\mathbf{0 . 4 4 3}$ & 0.586 & $\mathbf{0 . 9 8 6}^{*}$ \\
Pacific white-sided dolphin & 0.429 & $\mathbf{0 . 4 8 6}^{*}$ & 0.486 & -0.086 & 0.771 & 0.543 \\
Northern right whale dolphin & -0.414 & -0.200 & 0.414 & 0.143 & 0.300 & $\mathbf{0 . 3 1 4}$ \\
Dall's porpoise & 0.771 & $\mathbf{0 . 9 4 3}^{*}$ & 0.086 & -0.029 & 0.829 & $\mathbf{0 . 9 4 3}^{*}$ \\
\hline
\end{tabular}

from the summer shipboard surveys) were better than the model predictions for Pacific white-sided dolphin. However, given the limited sample sizes and 6 geographic data pairs for the correlation test, statistical power is low. Comparisons of predicted densities to observed aerial survey sightings and model-predicted abundance estimates to those derived from standard line-transect analyses suggest that the predictions were better than indicated by the rank correlation tests (Table 4, Fig. 5). All models showed good model fit (Table 2), emphasizing the importance of testing the explanatory power of a model prior to using it to make predictions on a novel dataset.

Because results varied by species, the models' ability to predict seasonal distribution patterns and capture known speciesenvironment relationships are discussed separately for each species below. 


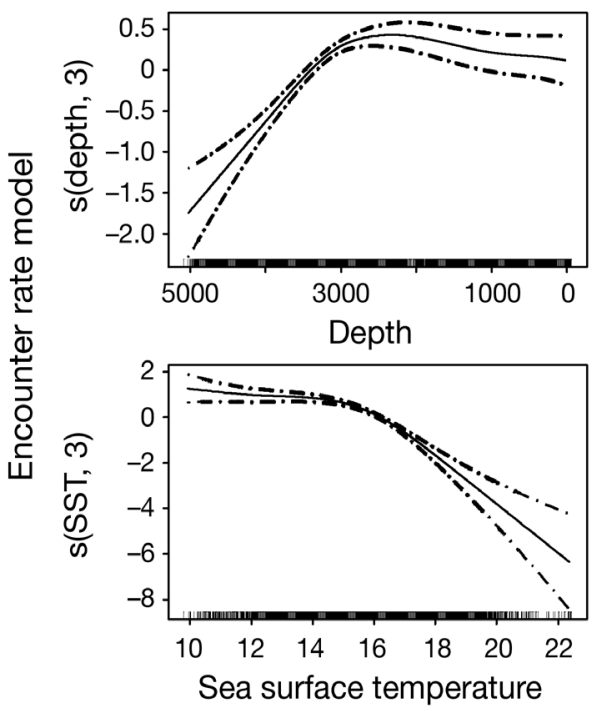

(d) Dall's porpoise
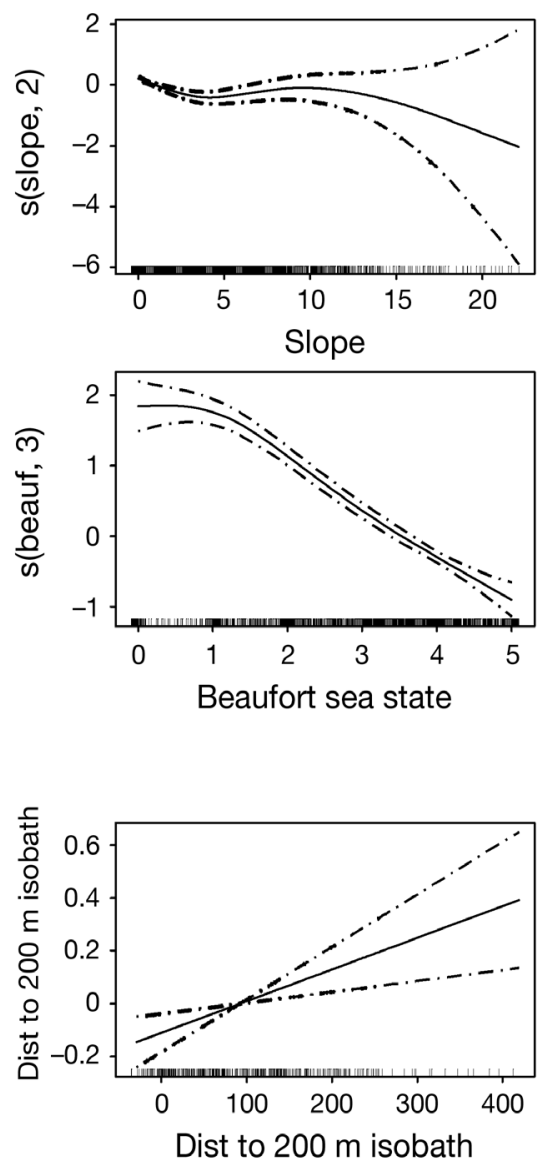
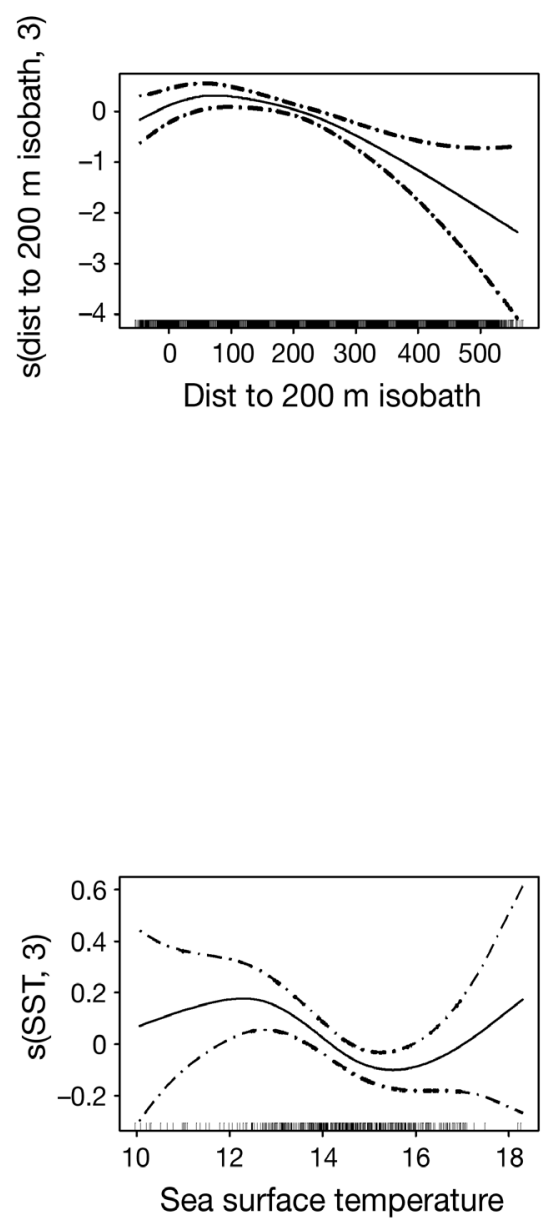

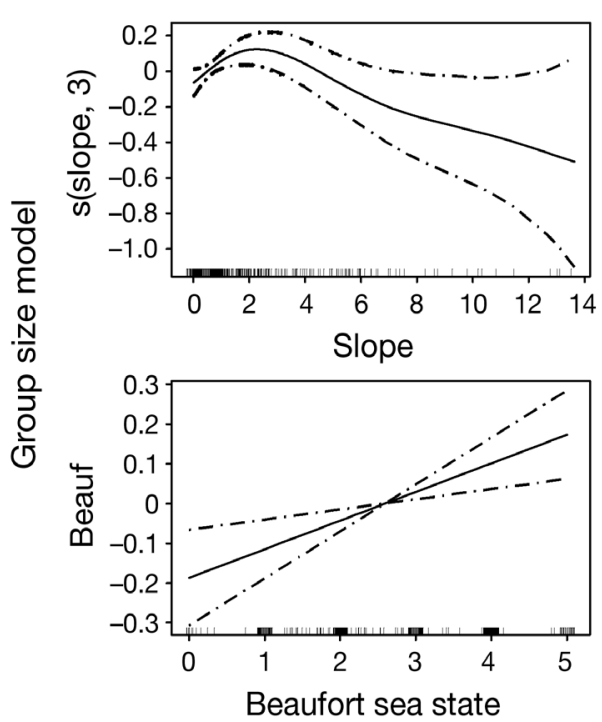

Delphinus spp.

Short-beaked and long-beaked common dolphins could not be reliably distinguished in the aerial surveys (Forney et al. 1995, Forney \& Barlow 1998), so the present analysis was limited to the entire genus; however, given the nearshore range of long-beaked common dolphins (Heyning \& Perrin 1994), most of the Delphinus spp. sightings from the surveys likely were short-beaked common dolphins. Significant seasonal differences in distribution have been documented for common dolphins off California; based on a statistical comparison of numbers of animals north and south of Point Arguello, and inshore/offshore of the $2000 \mathrm{~m}$ isobath, Forney \& Barlow (1998) identified a significant inshore/southerly shift in winter.

Predicted:observed density ratios for the total ship study area in summer were consistent with past modeling efforts (Barlow et al. 2009, Becker et al. 2010, 2012b, Forney et al. 2012), indicating within-season model robustness. These summer-based models effectively captured winter density patterns for the 6 geographic strata $(\mathrm{p}<0.05$; Table 3$)$. Visual comparison of the density predictions also indicate that the model was able to identify the inshore and southerly shift in distribution observed during winter 

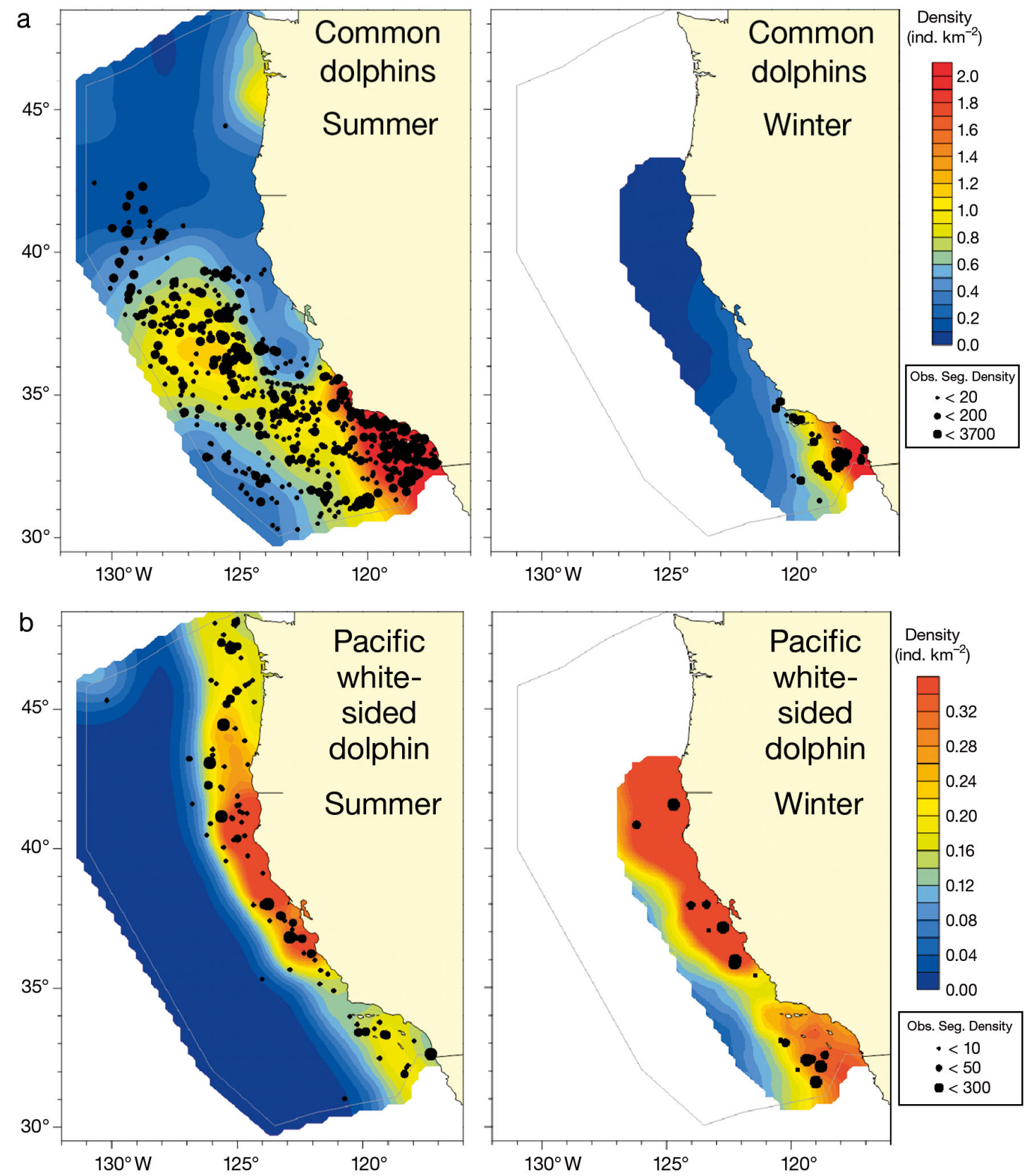

Fig. 5. Predicted densities from the summer/fall shipboard models based on summer/fall environmental data used for model building (left panels) and winter/spring environmental data (right panels), for (a) common dolphins, (b) Pacific white-sided dolphin, (c) northern right whale dolphin, and (d) Dall's porpoise. Predictions are shown for the study area (ship survey study area in left panels and aerial survey study area in right panels). Interpolation grids were created at a resolution of $25 \mathrm{~km}$, using inverse distance weighting to the second power in Surfer software (Version 9). The light gray line west and offshore of the aerial study area (right panels) marks the extent of the shipboard study area. Red (blue) represents highest (lowest) predicted density, as shown in the species-specific density keys. Black dots show actual sighting locations for the summer/fall ship surveys (left panels) and winter/spring aerial surveys (right panels), with larger dots representing more animals per surveyed segment (Obs. Seg. Density). For taxonomic names see Table 1

1991/92, and the model predictions were notably different than those for summer, when Delphinus spp. were predicted well north of Point Arguello and farther offshore (Fig. 5a).
The study area abundance of common dolphins during winter, as estimated from model predictions, was about half of that derived from standard linetransect analyses but well within the line-transect 

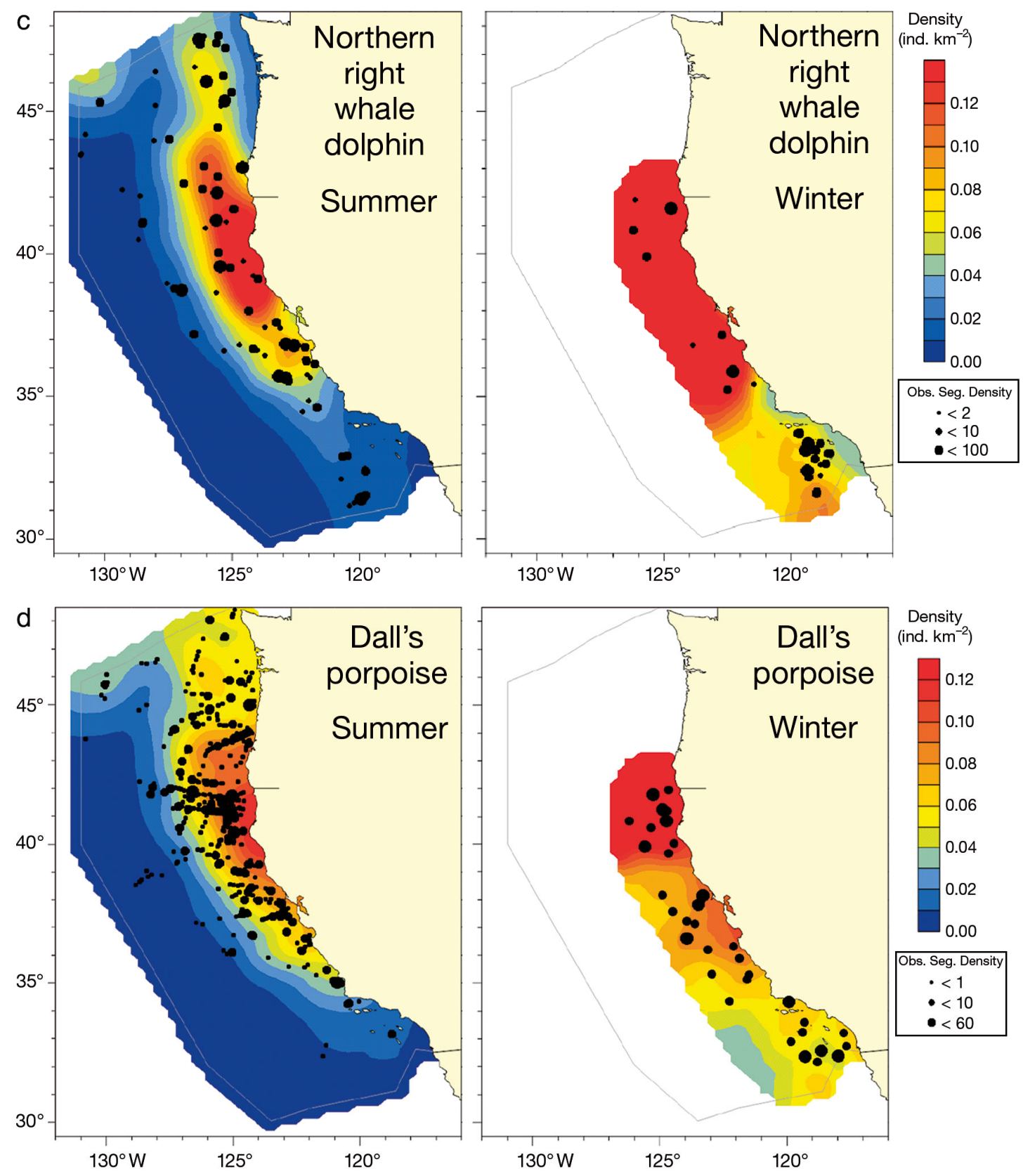

Fig. 5 (continued)

confidence limit (Table 4). Common dolphins typically occur in large groups, and availability bias is expected to be relatively small for the aerial surveys, but this would further increase the difference between the model- and survey-estimated values. The winter aerial surveys were conducted in 1991/92 during an El Niño year, when water temperatures off Southern California were anomalously high (Hayward 1993). Short-beaked common dolphins are a warm temperate to tropical species, and based on the models de- veloped here as well as in previous studies (Barlow et al. 2009, Becker et al. 2010, 2012b, Forney et al. 2012), densities are greatest when waters are warmest (Figs. 4a \& 5a). It is probable that there was a large influx of common dolphins into the study area in winter of 1991/92. The difference in abundance between the model estimate and the line-transect estimate could be caused by uncertainty in both estimates (within confidence limits), or it could be related to a potential El Niño-related influx of animals. 

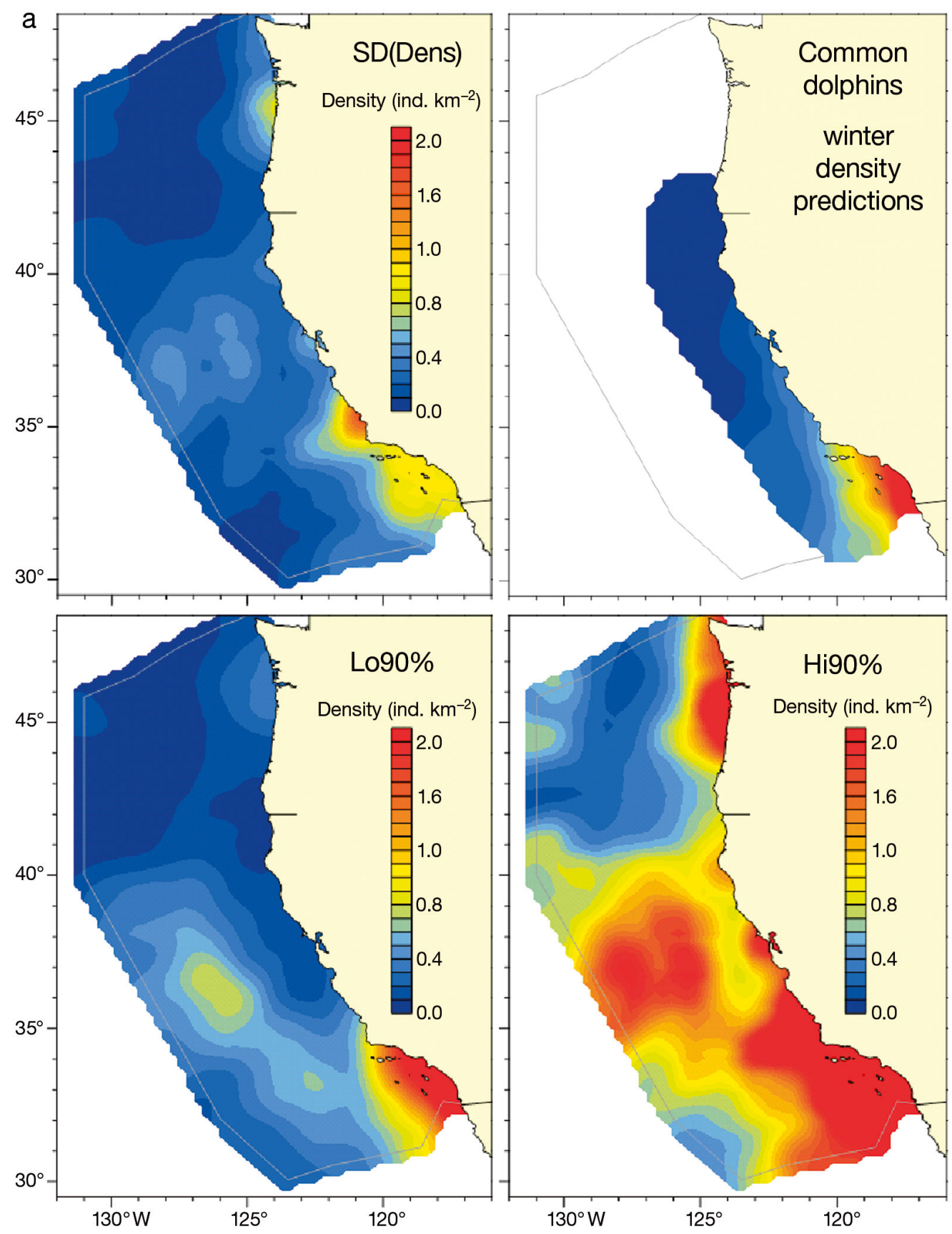

Fig. 6. Standard deviation (SD(Dens)), and upper and lower lognormal $90 \%$ confidence limits (Lo90\% and Hi90\%) based on the summer/fall models predicted on summer environmental data, and winter/spring density predictions for: (a) common dolphins, (b) Pacific white-sided dolphin, (c) northern right whale dolphin, and (d) Dall's porpoise. Predicted values for each survey year were interpolated using inverse distance weighting (see 'Methods' for details). Grid cells for each of the individual survey years were then averaged across all years and SD and upper and lower lognormal $90 \%$ confidence limits were calculated from the grid cell averages and variances using standard formulae. The light gray line marks the extent of the shipboard study area. Red (blue) represents highest (lowest) predicted density, as shown in the species-specific density keys. The density scale for the winter predictions has been scaled relative to the $90 \%$ confidence limits. For taxonomic names see Table 1

The northern extent of short-beaked common dolphin distribution off the US west coast varies on an interannual basis but is generally south of $45^{\circ} \mathrm{N}$ latitude (Smith et al. 1986, Forney \& Barlow 1998,
Hamilton et al. 2009). Interestingly, the average density predictions for summer showed an area of moderate density along the coast at approximately $45^{\circ} \mathrm{N}$ latitude (Fig. 5a), where, other than strandings 

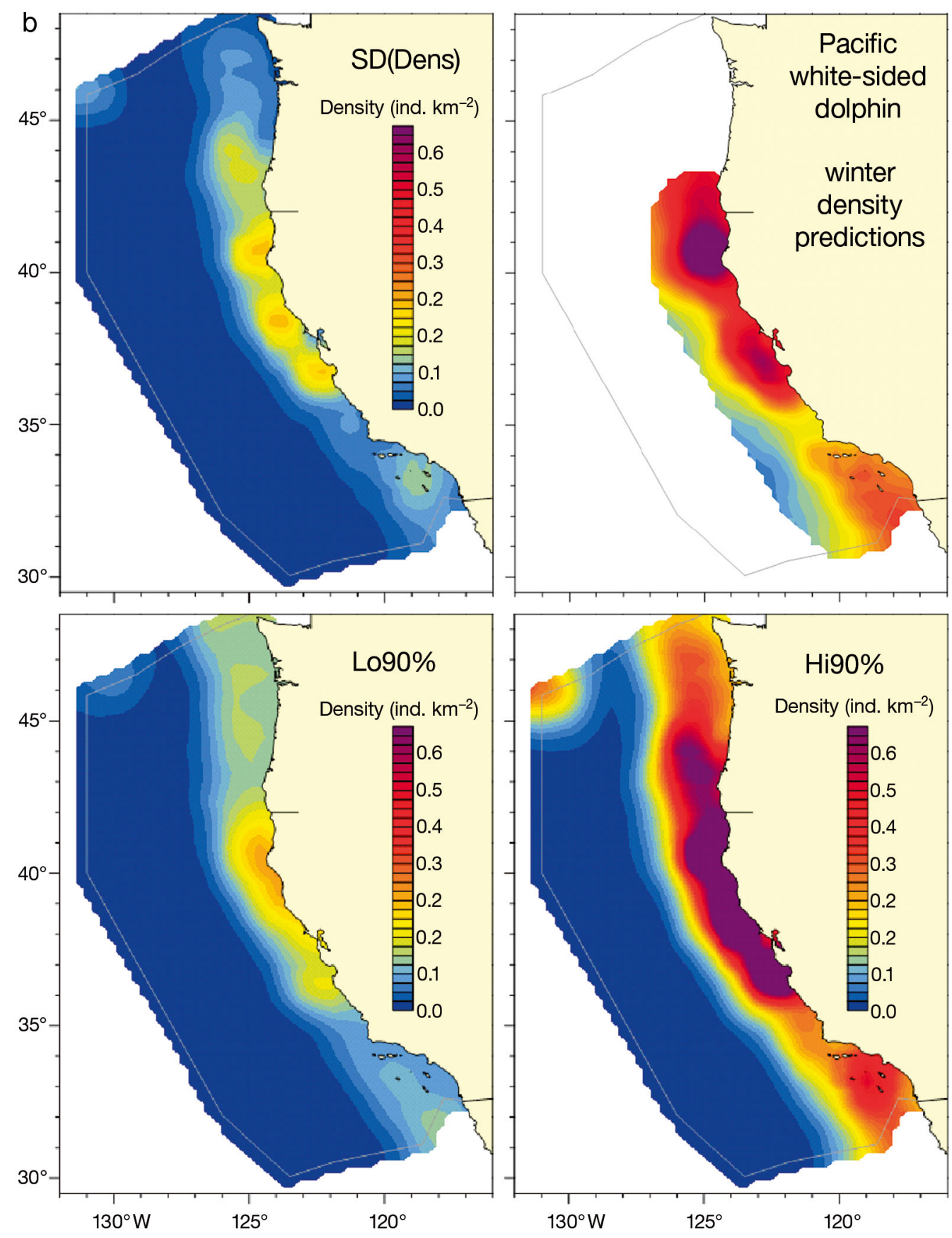

Fig. 6 (continued)

and occasional sightings, this species has not previously been documented (Barlow et al. 2009, Hamilton et al. 2009, Barlow 2010, Becker et al. 2012b, Forney et al. 2012). One group of approximately 40 short-beaked common dolphins was sighted off northern Washington at about $48^{\circ} \mathrm{N}$ latitude in 2005 (Forney 2007), but this was considered unusual. Short-beaked common dolphins are the most abun- dant cetacean species off the US west coast (Barlow 2010), and their distribution shifts with changing oceanic conditions (Barlow et al. 2009, Becker et al. 2012b, Forney et al. 2012), but insufficient data are currently available to resolve whether this higherdensity region identified by this summer model near $45^{\circ} \mathrm{N}$ has a biological basis or indicates potential mis-specification of the model. 

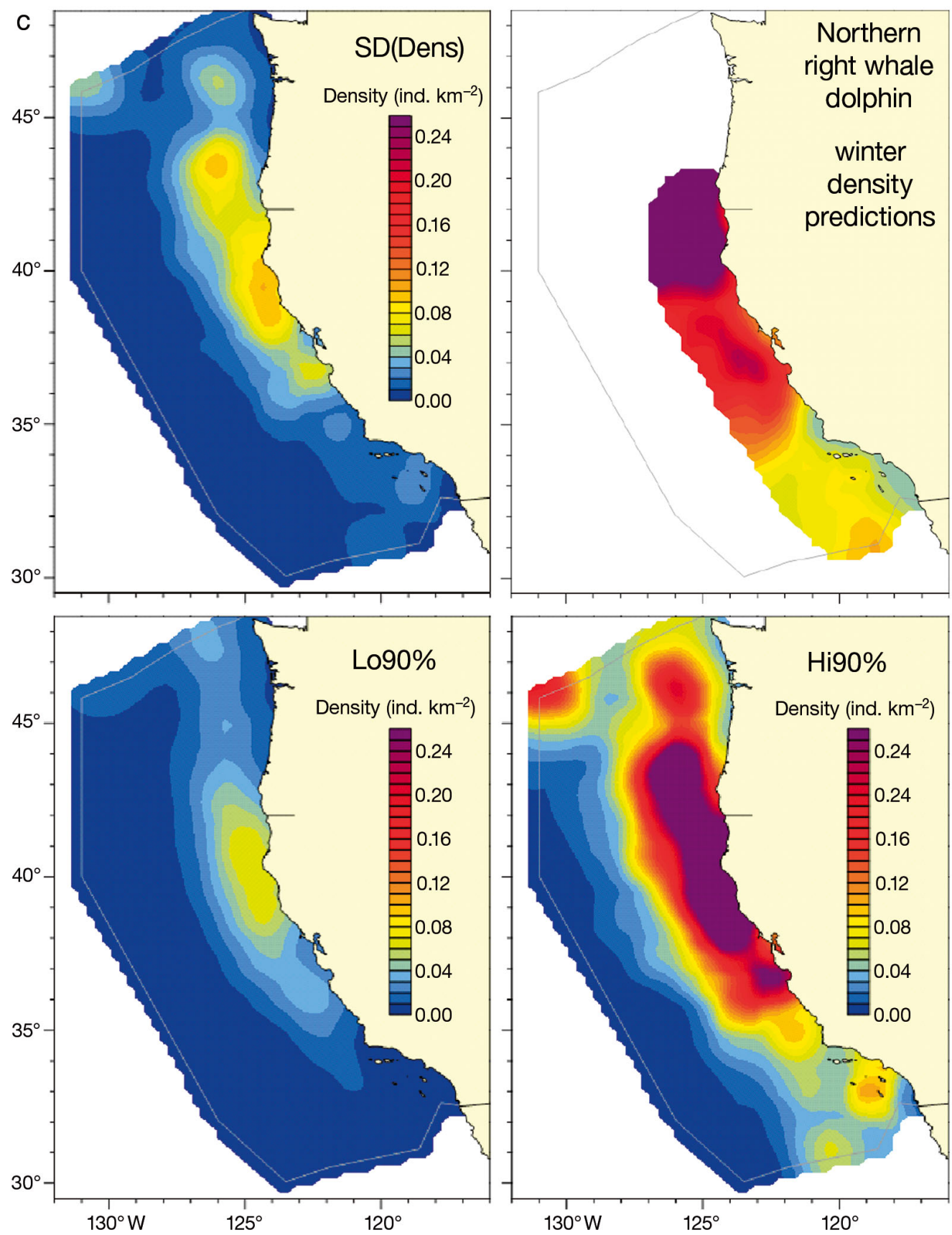

Fig. 6 (continued)

\section{Pacific white-sided dolphin}

Based on morphological and genetic evidence, 2 forms of Pacific white-sided dolphin occur in waters off California (Walker et al. 1986, Lux et al. 1997); however, they currently cannot be reliably distinguished in the field and are therefore treated together in the present analysis. Survey data indicate that the seasonal distribution of Pacific whitesided dolphins off the US west coast varies dramati- cally, as animals move north into waters off Oregon and Washington during the summer months and south into southern California waters during the winter months (Green et al. 1992, Forney \& Barlow 1998).

The stratum-specific modeled densities for Pacific white-sided dolphin failed to effectively predict winter density patterns as indicated by the rank correlation tests (Table 3). Visual inspection of the density plots for this species suggest that the mod- 

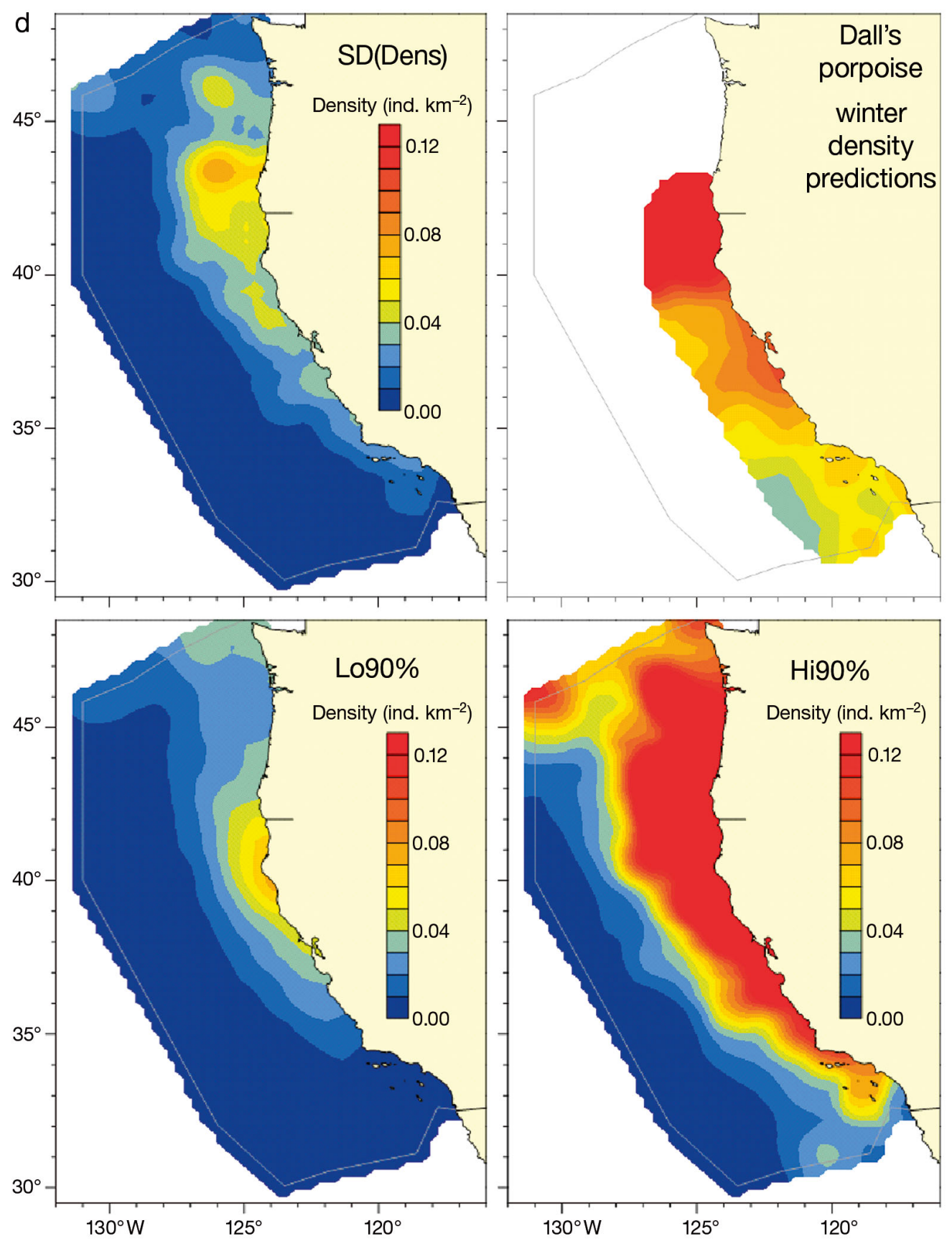

Fig. 6 (continued)

els' predictive ability was better than indicated, however, because greater densities were predicted south of about $33^{\circ} \mathrm{N}$ latitude, where large numbers of Pacific white-sided dolphins were sighted during the 1991/92 aerial surveys (Fig. 5b). Further, compared to the predicted density patterns in summer, a clear southerly shift in distribution is evident in the winter plot, indicating that the summer-based models more closely match the observed winter patterns.
The estimated winter abundance of Pacific whitesided dolphins based on model predictions was similar to (within $12 \%$ of) the estimate derived from standard line-transect analyses (Table 4). A higher proportion of animals is expected to be missed during aerial surveys due to availability bias, so the actual difference may be greater than indicated; however, Pacific white-sided dolphins commonly occur in large, asynchronously diving groups, so the magnitude of the aerial survey availability bias is expected to be small. 
Table 4. Modeled abundance estimates (Model) and those derived from survey observations by Forney et al. (1995) using standard line-transect analyses (line-transect). Bootstrap confidence intervals (CIs, shown with lower and upper 95th percentiles) were recalculated from the original line-transect data using the $\mathrm{BC}_{\mathrm{a}}$ method (Efron \& Tibshirani 1993). Taxonomic names are given in Table 1

\begin{tabular}{|lrrrr|}
\hline Species & \multicolumn{2}{c}{$\begin{array}{c}\text { Winter abundance } \\
\text { estimates }\end{array}$} & \multicolumn{2}{c|}{$\begin{array}{c}\text { Line-transect } \\
\text { bootstrap CIs }\end{array}$} \\
& Model Line-transect & L95\% & U95\% \\
\hline Common dolphins & 156010 & 305694 & 124493 & 541163 \\
Pacific white-sided dolphin & 108338 & 121693 & 35625 & 261931 \\
Northern right whale dolphin & 66875 & 21332 & 9902 & 46147 \\
Dall's porpoise & 21841 & 26111 & 14919 & 46201 \\
\hline
\end{tabular}

periods off California, with more animals present during the cold water period. The estimated winter abundance of northern right whale dolphin based on model predictions was almost 3 times higher than the estimate derived from standard line-transect analyses, and well above the upper 95\% confidence interval (Table 4). A higher proportion of animals is expected to be missed during the aerial surveys due to availability bias; however, it is unlikely that the magnitude of this bias would be large enough to account for the difference in model-predicted versus linetransect-derived density estimates. The overestimate is likely the result of the models predicting outside the range of values used to build them as noted above. In summary, while the models exhibited some ability to predict seasonal shifts in distribution, more data collected over a range of oceanic conditions are needed to make the models robust and allow them to more accurately predict absolute abundance throughout the study area.

\section{Dall's porpoise}

Previous analyses of a portion of the cetacean sighting data used for this study found a statistically significant seasonal difference in the distribution of Dall's porpoise north and south of Point Arguello, documenting a southward shift during winter (Forney \& Barlow 1998). The summer model's ability to capture the seasonal distribution shift was significant $(\mathrm{p}<0.05)$ as indicated by the rank correlation test (Table 3). Visual comparison of the density predictions also indicate that the model was able to identify the southerly shift in distribution observed during winter 1991/92. Dall's porpoise was predicted to occur well south of Point Arguello, consistent with the winter survey sightings and notably different than the summer distribution pattern in the Southern California Bight (Fig. 5d).

The model-predicted abundance estimate for the winter study area was very similar to that derived from standard line-transect analyses, and well within the $95 \%$ confidence interval of the latter (Table 4). Availability bias was accounted for in the line-transect abundance estimate for Dall's porpoise (Forney \& Barlow 1998), and this may have contributed to the similarity in estimates derived from the summer model predictions. 


\section{Seasonal predictions}

In many regions with clearly distinctive seasonal differences (e.g. polar regions), it would not be appropriate to use models built with summer data in an attempt to make winter predictions. Acrossseason predictions also are not appropriate for highly migratory species, e.g. many baleen whales that are known to be absent from the study area during one season and present in another, unless this migratory pattern is included in the model. Social organization and behavioral aspects of species ecology may also confound the cetacean-habitat modeling approach, particularly when attempting to predict across seasons. In addition, anthropogenic activity may deter animals from preferred habitat, further confounding predictions from habitat models. For species present in an area year-round and known to have pronounced seasonal distribution shifts, the results of this study indicate that spatially explicit habitat models can be valuable tools for assessing species distributions in a temporally dynamic environment, although model accuracy is directly related to the degree to which the models can capture year-round habitat conditions.

A notable difference between our study and an initial evaluation of across-season predictive ability using a subset of these data (Becker 2007) was the number of sightings available to build and evaluate the models. The initial analysis relied on SST satellite data measured from passive infrared sensors (e.g. Pathfinder), which creates data gaps due to cloud cover. In the present study we used a more recent satellite-derived SST product that blends in situ and infrared sensor measurements and virtually eliminates data gaps due to cloud cover (Reynolds et al. 2007). On a species-specific basis, this increased the number of summer ship survey sightings available to build the models by up to $54 \%$ for the years included in the initial study (1991 to 2001) and increased the number of winter aerial survey sightings used to evaluate the predictions by up to $30 \%$. Further, the present study included 2 additional years of ship survey data (2005 and 2008) and expanded the study area north to include waters off Oregon and Washington, thus including a broader range of environmental conditions for model development. These improvements resulted in more robust models, as demonstrated by the increased explanatory and predictive power of the models.

SST was the only dynamic environmental predictor variable included in the models used in the present study. Remotely sensed measures of chlorophyll could not be included because they were not avail- able during 1991 to 1996, and satellite-derived salinity measurements have only been available since 2011. Further improvements to across-season predictions may be realized with the inclusion of additional environmental variables, particularly those that provide a more direct link to cetacean prey, such as zooplankton indices currently available from in situ data (Redfern et al. 2008, Barlow et al. 2009). Although the use of such predictors may improve model performance, collecting and processing in situ oceanographic data requires substantial time and expense, and predictive models that rely on in situ data may not be as useful to resource managers who are often required to make timely decisions related to protected species abundance and distribution. For cetacean species that require more complex habitat models that include predictor variables such as mixed layer depth and prey indices (Redfern et al. 2008, Barlow et al. 2009, Becker et al. 2012b, Forney et al. 2012), near real-time and forecast predictions from ocean circulation models (e.g. Chao et al. 2009) may provide a means to improve across-season predictions.

\section{Methodology}

Differences in species distribution may arise from variability in the number of groups in a given area or variability in group size, with potentially different environmental factors affecting the 2 parameters. To account for these differences, density estimates are typically derived from separate encounter rate and group size models using appropriate statistical distributions (Ferguson et al. 2006, Redfern et al. 2008, Barlow et al. 2009, Becker et al. 2010, 2012a,b, Forney et al. 2012). For species that typically occur in small groups (e.g. some baleen whales), the number of individual animals can be modeled as a single response variable (e.g. Redfern et al. 2013). Large variability in group size is evident for the delphinids addressed in this study, and hence we developed separate group size models. However, the lack of success in predicting group size in this and other studies (e.g. Ferguson et al. 2006, Redfern et al. 2008) suggests that either we are not including the appropriate environmental variables in our models or there are other non-environmental variables determining group size (e.g. social organization, predator protection, behavioral aspects; Reilly \& Fiedler 1994). Future studies should evaluate alternative sampling distributions for modeling encounter rate and group size as a single response variable for species with large group size variability in order to better capture spatial patterns. 


\section{Implications for marine spatial planning}

Effective pelagic conservation planning requires broad-scale information on species density across space and time, but management is often limited by the lack of data. This study was designed to evaluate the extent to which cross-season predictions might be valid within the CCE, a temporally dynamic environment. Results suggest that, although the processes of interannual and seasonal variability are different, interannual variability in the environmental parameters can be large enough to explain some of the variation in the seasonal distribution patterns of cetaceans in the waters off California. More importantly, models need to be developed using environmental parameters that include the full range of conditions for the temporal/spatial period they are predicting.

Ideally, cetacean survey data would be collected for the specific time period of interest and spatial habitat models built accordingly. However, in most areas cetacean survey data are biased towards summer (Kot et al. 2010). In the absence of actual survey data, results suggest that the seasonal geographic patterns of species density were captured effectively for most species, and demonstrate that there is potential to improve our decision-making through such models, but limitations and caveats must be considered. In this case, for marine planning activities that require an understanding of winter species distribution in order to assess and minimize potential impacts, the across-season predictions are more informative than the complete absence of data or the reliance on summer distribution patterns. In terms of estimating the total number of animals potentially exposed to a given anthropogenic activity, the model-derived density estimates would need to be applied cautiously on a species-by-species basis, with the recognition that in some cases the out-ofbound predictions could produce unrealistic results. For example, since the linear SST function in the group size model for northern right whale dolphins contributed to overpredictions of winter densities, a constant group size estimate could be used in concert with the encounter rate model to eliminate this effect on the density estimates. With the recognition of model limits, habitat-based density models can be valuable tools for assessing species distributions and informing pelagic management decisions.

Acknowledgements. We thank everyone who spent long hours collecting the data used in our analyses, including the marine mammal observers, cruise leaders, officers, and crew of the RV 'David Starr Jordan,' RV 'McArthur,' and RV
'McArthur II,' as well as the marine mammal observers, data recorders, and pilots responsible for the 1991/92 aerial surveys. Chief Scientists for the ship survey cruises included T. Gerrodette and 2 of the co-authors (J.B. and K.A.F.). This paper was improved by reviews from S. Benson, J. Carretta, A. Dransfield, and 1 anonymous referee. Special thanks to J. Michaelsen, J. Richardson, and L. Washburn for their constructive comments on earlier versions of this manuscript. Funding for this project was provided by the Strategic Environmental Research and Development Program (SERDP), under Conservation Project CS-1391, and the Southwest Fisheries Science Center.

\section{LITERATURE CITED}

Akaike H (1973) Information theory and an extension of the maximum likelihood principle. In: Petran BN and Csàaki F (eds) 2nd Int Symp Inf Theory. Akadèemiai Kiadi, Budapest, p 267-281

Amante C, Eakins BW (2009) ETOPO1 1 arc-minute global relief model: procedures, data sources and analysis. Tech Memo NESDIS NGDC-24. National Geophysical Data Center, Boulder, CO

Barber RT, Chavez FP (1983) Biological consequences of El Niño. Science 222:1203-1210

Barber RT, Smith RL (1981) Coastal upwelling ecosystems. In: Longhurst AR (ed) Analysis of marine ecosystems. Academic Press, New York, NY, p 31-68

Barlow J (2003) Preliminary estimates of the abundance of cetaceans along the U.S. west coast: 1991-2001. NOAA Admin Rep LJ-03-03. Southwest Fisheries Science Center, National Marine Fisheries Service, La Jolla, CA

Barlow J (2010) Cetacean abundance in the California Current estimated from a 2008 ship-based line-transect survey. NOAA Tech Memo NMFS-SWFSC-456

Barlow J, Forney KA (2007) Abundance and density of cetaceans in the California Current ecosystem. Fish Bull 105:509-526

Barlow J, Gerrodette T, Forcada J (2001) Factors affecting perpendicular sighting distances on shipboard line-transect surveys for cetaceans. J Cetacean Res Manag 3: 201-212

Barlow J, Ferguson MC, Becker EA, Redfern JV and others (2009) Predictive modeling of cetacean densities in the eastern Pacific Ocean. NOAA Tech Memo NMFSSWFSC-444

> Barlow J, Calambokidis J, Falcone EA, Baker CS and others (2011) Humpback whale abundance in the North Pacific estimated by photographic capture-recapture with bias correction from simulation studies. Mar Mamm Sci 27: 793-818

Becker EA (2007) Predicting seasonal patterns of California cetacean density based on remotely sensed environmental data. PhD dissertation, University of California, Santa Barbara, CA

Becker EA, Forney KA, Ferguson MC, Foley DG, Smith RC, Barlow J, Redfern JV (2010) Comparing California Current cetacean-habitat models developed using in situ and remotely sensed sea surface temperature data. Mar Ecol Prog Ser 413:163-183

Becker EA, Foley DG, Forney KA, Barlow J, Redfern JV, Gentemann CL (2012a) Forecasting cetacean abundance patterns to enhance management decisions. Endang Species Res 16:97-112 
Becker EA, Forney KA, Ferguson MC, Barlow J, Redfern JV (2012b) Predictive modeling of cetacean densities in the California Current ecosystem based on summer/fall ship surveys in 1991-2008. NOAA Tech Memo NMFSSWFSC-499

Briggs JC (1974) Marine zoography. McGraw-Hill, New York, NY

Buckland ST, Anderson DR, Burnham KP, Laake JL, Borchers DL, Thomas L (2001) Introduction to distance sampling: estimating abundance of biological populations. Oxford University Press, Oxford

Calambokidis J, Steiger GH, Rasmussen K, Urban J and others (2000) Migratory destinations of humpback whales that feed off California, Oregon and Washington. Mar Ecol Prog Ser 192:295-304

Calambokidis J, Barlow J, Ford KB, Chandler TE, Douglas AB (2009) Insights into the population structure of blue whales in the eastern North Pacific from recent sightings and photographic identifications. Mar Mamm Sci 25: 816-832

Cañadas A, Sagarminaga R, García-Tiscar S (2002) Cetacean distribution related with depth and slope in the Mediterranean waters off southern Spain. Deep-Sea Res I 49:2053-2073

Carretta JV, Forney KA (1993) Report of the two aerial surveys for marine mammals in California waters utilizing a NOAA DeHavilland Twin Otter aircraft, March 9-April 7, 1991 and February 8-April 6, 1992. NOAA Tech Memo NOAA-TM-NMFS-SWFSC-185

Chao Y, Li Z, Farrara J, McWilliams JC and others (2009) Development, implementation and evaluation of a dataassimilative ocean forecasting system off the central California coast. Deep-Sea Res II 56:100-126

Chavez FP, Ryan J, Lluch-Cota SE, Niquen CM (2003) From anchovies to sardines and back: multidecadal change in the Pacific Ocean. Science 299:217-221

Dohl TP, Norris KS, Guess RC, Bryant JD, Honig MW (1978) Summary of marine mammal and seabird surveys of the Southern California Bight area, 1975-78, Vol III: investigators' reports, Part II: Cetacea of the Southern California Bight. Final Report to the Bureau of Land Management, NTIS Catalog No. PB81-248189. University of California, Santa Cruz, CA

Dohl TP, Guess RC, Duman ML, Helm RC (1983) Cetaceans of central and northern California, 1980-1983: status, abundance, and distribution. Prepared for Pacific OCS Region, Minerals Management Service, U.S. Department of the Interior. Contract No. 14-12-0001-29090, NTIS Catalog No. PB85-183861. Pacific OCS Region, Minerals Management Service, US Dept. of the Interior, Los Angeles, CA

Dohl TP, Bonnell ML, Ford RG (1986) Distribution and abundance of common dolphin, Delphinus delphis, in the Southern California Bight: a quantitative assessment based upon aerial transect data. Fish Bull 84:333-343

Doyle RF (1985) Biogeographical studies of rocky shore near Point Conception, California. PhD dissertation, University of California, Santa Barbara, CA

Edwards EF, Perkins PC (1992) Power to detect linear trends in dolphin abundance: estimates from tuna-vessel observer data, 1975-89. Fish Bull 90:625-631

Efron B, Tibshirani RJ (1993) An introduction to the bootstrap. Chapman and Hall, London

> Ferguson MC, Barlow J, Fiedler P, Reilly SB, Gerrodette T (2006) Spatial models of delphinid (family Delphinidae) encounter rate and group size in the eastern tropical Pacific Ocean. Ecol Model 193:645-662

Forney KA (1999) Trends in harbor porpoise abundance off central California, 1986-95; evidence for interannual change in distribution? J Cetacean Res Manag 1:73-80

Forney KA (2000) Environmental models of cetacean abundance: reducing uncertainty in population trends. Conserv Biol 14:1271-1286

Forney KA (2007) Preliminary estimates of cetacean abundance along the U.S. west coast and within four National Marine Sanctuaries during 2005. NOAA Tech Memo NMFS-SWFSC-406

Forney KA, Barlow J (1998) Seasonal patterns in the abundance and distribution of California cetaceans, 19911992. Mar Mamm Sci 14:460-489

Forney KA, Hanan DA, Barlow J (1991) Detecting trends in harbor porpoise abundance from aerial surveys using analysis of covariance. Fish Bull 89:367-377

Forney KA, Barlow J, Carretta JV (1995) The abundance of cetaceans in California waters. Part II: aerial surveys in winter and spring of 1991 and 1992. Fish Bull 93:15-26

Forney KA, Ferguson MC, Becker EA, Fiedler PC and others (2012) Habitat-based spatial models of cetacean density in the eastern Pacific Ocean. Endang Species Res 16: 113-133

Gerrodette T, Eguchi T (2011) Precautionary design of a marine protected area based on a habitat model. Endang Species Res 15:159-166

Gilles A, Adler S, Kaschner K, Scheidat M, Siebert U (2011) Modelling harbour porpoise seasonal density as a function of the German Bight environment: implications for management. Endang Species Res 14:157-169

> Goetz KT, Montgomery RA, Ver Hoef JM, Hobbs RC, Johnson DS (2012) Identifying essential summer habitat of the endangered beluga whale Delphinapterus leucas in Cook Inlet, Alaska. Endang Species Res 16:135-147

Green GA, Brueggeman JJ, Grotefendt RA, Bowlby CE, Bonnell ML, Balcomb KC III (1992) Cetacean distribution and abundance off Oregon and Washington, 1989-1990. In: Oregon and Washington marine mammal and seabird surveys. In: Brueggeman JJ (ed) OCS Study MMS 910093, contract 14-12-0001-30426. U.S. Department of the Interior, Minerals Management Service, Los Angeles, CA, p 1-100

Green GA, Grotefendt RA, Smultea MA, Bowlby CE, Rowlett RA (1993) Delphinid aerial surveys in Oregon and Washington offshore waters. Contract No. 50ABNF200058. Final report prepared for NMFS. National Marine Mammal Lab, Alaska Fisheries Science Center, Seattle, WA

Hamilton TA, Redfern JV, Barlow J, Ballance LT and others (2009) Atlas of cetacean sightings for Southwest Fisheries Science Center cetacean and ecosystem surveys: 1986-2005. NOAA Tech Memo NMFS-SWFSC-440

Hastie TJ, Tibshirani RJ (1990) Generalized additive models, Vol 43. Chapman \& Hall/CRC, Boca Raton, FL

Hayward TL (1993) Preliminary observations of the 19911992 El Niño in the California Current. Calif Coop Ocean Fish Invest Rep 34:21-29

Heyning JE, Perrin WF (1994) Evidence for two species of common dolphin (genus Delphinus) from the eastern North Pacific. Los Angel Cty Mus Nat Hist Contrib Sci 442:1-35

Hickey BM (1979) The California Current System-hypotheses and facts. Prog Oceanogr 8:191-279 
Hooker SK, Whitehead H, Gowans S (1999) Marine protected area design and the spatial and temporal distribution of cetaceans in a submarine canyon. Conserv Biol 13:592-602

Kaschner K, Watson R, Trites AW, Pauly D (2006) Mapping world-wide distributions of marine mammal species using a relative environmental suitability (RES) model. Mar Ecol Prog Ser 316:285-310

Keller CA, Garrison L, Baumstark R, Ward-Geiger LI, Hines E (2012) Application of a habitat model to define calving habitat of the North Atlantic right whale in the southeastern United States. Endang Species Res 18:73-87

Kinzey D, Olson P, Gerrodette T (2000) Marine mammal data collection procedures on research ship line-transect surveys by the Southwest Fisheries Science Center. Report No. LJ-00-08. Southwest Fisheries Science Center, La Jolla, CA

> Koslow JA, Hobday AJ, Boehlert GW (2002) Climate variability and marine survival of coho salmon (Oncorhynchus kisutch) in the Oregon production area. Fish Oceanogr 11:65-77

Kot CY, Fujioka E, Hazen LJ, Best BD, Read AJ, Halpin PN (2010) Spatio-temporal gap analysis of OBIS-SEAMAP project data: assessment and way forward. PLoS ONE 5: e12990

Leatherwood S, Walker WA (1979) The northern right whale dolphin Lissodelphis borealis Peale in the eastern North Pacific. In: Winn HE, Olla BL (eds) Behavior of marine animals, Vol 3: cetaceans. Plenum Press, New York, NY, p 85-141

Lux CA, Costa AS, Dizon AE (1997) Mitochondrial DNA population structure of the Pacific white-sided dolphin. Rep Int Whal Comm 47:645-652

Lynn RJ, Simpson JJ (1987) The California Current system: the seasonal variability of its physical characteristics. J Geophys Res 92:12947-12966, doi:10.1029/JC092iC12p 12947

Mantua NJ, Hare SR (2002) The Pacific Decadal Oscillation. J Oceanogr 58:35-44

> Maravelias CD, Reid DG, Swartzman G (2000) Modelling spatio-temporal effects of environment on Atlantic herring, Clupea harengus. Environ Biol Fishes 58: $157-172$

Marsh H, Sinclair DF (1989) Correcting for visibility bias in strip transect aerial surveys of aquatic fauna. J Wildl Manag 53:1017-1024

McGowan JA, Cayan DR, Dorman LM (1998) Climate-ocean variability and ecosystem response in the Northeast Pacific. Science 281:210-216

Newman WA (1979) California transition zone: significance of short-range endemics. In: Gray J, Boucot AJ (eds) Historical biogeography, plate tectonics, and the changing environment. Oregon State University Press, Corvallis, OR, p 399-416

Palacios DM, Bograd SJ, Foley DG, Schwing FB (2006) Oceanographic characteristics of biological hot spots in the North Pacific: a remote sensing perspective. DeepSea Res II 53:250-269

Peterman RM, Bradford MJ (1987) Statistical power of trends in fish abundance. Can J Fish Aquat Sci 44: 1879-1889

Pyper BJ, Peterman RM (1999) Relationship among adult body length, abundance, and ocean temperature for British Columbia and Alaska sockeye salmon (Oncorhynchus nerka), 1967-1997. Can J Fish Aquat Sci 56: 1716-1720

Ralls K, Taylor BL (2000) Better policy and management decisions through explicit analysis of uncertainty: new approaches from marine conservation. Conserv Biol 14: 1240-1242

Redfern JV, Barlow J, Ballance LT, Gerrodette T, Becker EA (2008) Absence of scale dependence in dolphin-habitat models for the eastern tropical Pacific Ocean. Mar Ecol Prog Ser 363:1-14

Redfern JV, McKenna MF, Moore TJ, Calambokidis J and others (2013) Assessing the risk of ships striking large whales in marine spatial planning. Conserv Biol 27: 292-302

Reid JL, Roden GI, Wyllie JG (1958) Studies of the California Current System. Calif Coop Oceanic Fish Invest Rep 1 July 1956 to 1 January 1958, 6:27-56

Reilly SB, Fiedler PC (1994) Interannual variability of dolphin habitats in the eastern tropical Pacific. I. Research vessel surveys, 1986-1990. Fish Bull 92:434-450

> Reynolds RW, Smith TM (1994) Improved global sea surface temperature analyses using optimum interpolation. J Clim 7:929-948

Reynolds RW, Smith TM, Liu C, Chelton DB, Casey KS, Schlax MG (2007) Daily high-resolution-blended analyses for sea surface temperature. J Clim 20:5473-5496

Rosel PE, Dizon AE, Heyning JE (1994) Genetic analysis of sympatric morphotypes of common dolphins (genus Delphinus). Mar Biol 119:159-167

Rosenkranz GE, Tyler AV, Kruse GH (2001) Effects of water temperature and wind on year-class success of Tanner crabs in Bristol Bay, Alaska. Fish Oceanogr 10:1-12

Schwing FB, Moore CS, Ralston S, Sakuma KM (2000) Record coastal upwelling in the California Current in 1999. Calif Coop Ocean Fish Invest Rep 41:148-160

Smith RC, Dustan P, Au PD, Baker KS, Dunlap EA (1986) Distribution of cetacean and sea-surface chlorophyll concentrations in the California Current. Mar Biol 91: 385-402

> Swartz SL, Taylor BL, Rugh DJ (2006) Gray whale Eschrichtius robustus population and stock identity. Mammal Rev 36:66-84

Taylor BL, Gerrodette T (1993) The uses of statistical power in conservation biology: the vaquita and northern spotted owl. Conserv Biol 7:489-500

Torres LG, Rosel PE, D'Agrosa C, Read AJ (2003) Improving management of overlapping bottlenose dolphin ecotypes through spatial analysis and genetics. Mar Mamm Sci 19: 502-514

Valentine JW (1973) Evolutionary paleoecology of the marine biosphere. Prentice-Hall, Englewood Cliffs, NJ

Walker WA, Leatherwood S, Goodrich KR, Perrin WF, Stroud RK (1986) Geographical variation and biology of the Pacific white-sided dolphin, Lagenorhynchus obliquidens, in the north-eastern Pacific. In: Bryden MM, Harrison R (eds) Research on dolphins. Clarendon Press, Oxford, p 441-465

> Wang Z, Bovik AC, Sheikh HR, Simoncelli EP (2004) Image quality assessment: from error visibility to structural similarity. IEEE Trans Image Process 13:600-612 